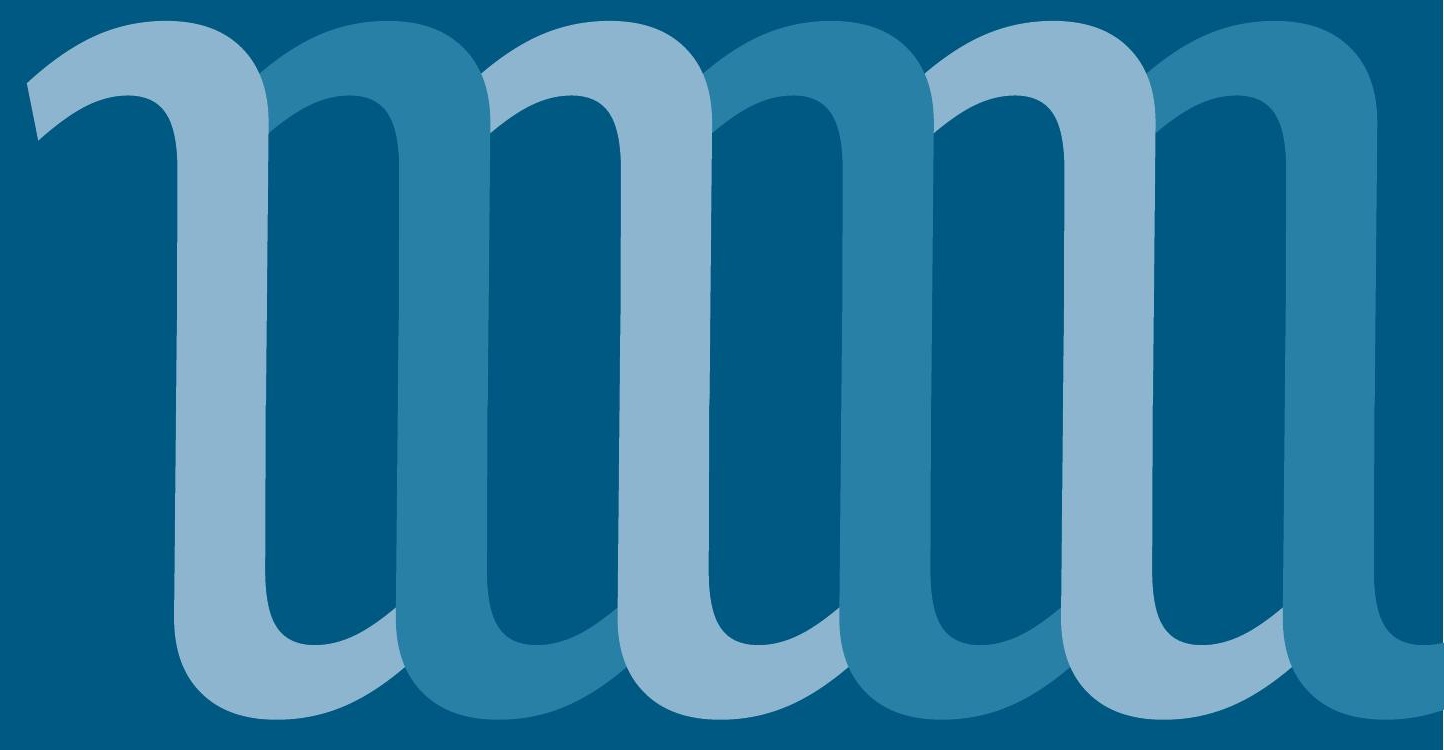

\title{
Komercializacija novosti za neekonomiste
}

Dragan Kesič Borut Likar

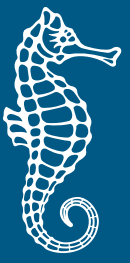


Učbeniki

Fakultete za management

Glavni urednik

Matjaž Novak

Uredniški odbor

Ana Arzenšek

Štefan Bojnec

Dubravka Celinšek

Armand Faganel

Viktorija Florjančič

Borut Kodrič

Suzana Laporšek

Mirko Markič

Franko Milost

Matjaž Nahtigal

Mitja Ruzzier

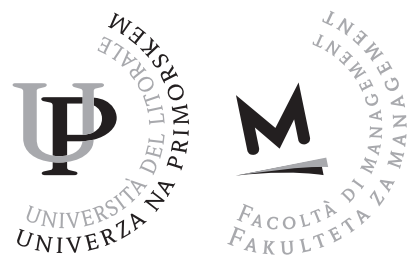




\section{Komercializacija novosti za neekonomiste}

Dragan Kesič

Borut Likar

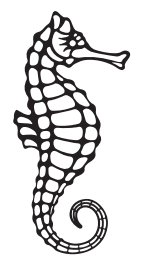


Komercializacija novosti za neekonomiste

Dragan Kesič

Borut Likar

Recenzent $\cdot$ Milan Jurše

Oblikovanje in tehnična ureditev · Alen Ježovnik

Izdala in založila $\cdot$ Založba Univerze na Primorskem

Titov trg 4, 60oo Koper

www.hippocampus.si

Glavni urednik · Jonatan Vinkler

Vodja založbe · Alen Ježovnik

Koper, marec 2018

(c) 2018 Univerza na Primorskem

http://www.hippocampus.si/ISBN/978-961-7023-88-6.pdf

http://www.hippocampus.si/ISBN/978-961-7023-89-3/index.html

https://doi.org/10.26493/978-961-7023-88-6

\section{(9) $(1) \Theta$}

Kataložni zapis o publikaciji (CIP) pripravili

v Narodni in univerzitetni knjižnici v Ljubljani

C O B I S S . S I - I D $=293915904$

I S B N 978-961-7023-88-6 (pdf)

IS B N 978-961-7023-89-3 (html) 


\section{Kazalo}

Seznam slik in preglednic $\cdot 6$

$1 \mathrm{Uvod} \cdot 7$

2 Osnove delovanja gospodarstva $\cdot 9$

3 Temeljno o delovanju in poslovanju podjetij · 15

4 Osnovno o trgu in tržni strukturi · 23

5 Povpraševanje in ponudba $\cdot 27$

6 Vloga izdelka in storitve v komercializaciji · 31

7 Marketing in komercializacija 33

8 Osnovne aktivnosti komercializacije $\cdot 35$

9 Sodobni načini komercializacije (e-poslovanje) · 39

10 Preverjanje novosti na trgu $\cdot 41$

10.1 Spremljanje tehnološkega stanja (technology watch) $\cdot 41$

10.2 Preverjanje patentnih baz $\cdot 43$

10.3 Preverjanje konkurenčnih tržnih proizvodov $\cdot 45$

11 Oblike komercializacije novosti $\cdot 49$

11.1 Podjetniška dejavnost $\cdot 49$

11.2 Prodaja invencije oziroma intelektualne lastnine $\cdot 51$

11.3 Načini prodaje licence $\cdot 54$

12 Podporno okolje glede financiranja in komercializacije · 59

12.1 Financiranje 59

12.2 Podpora pri razvoju in komercializaciji $\cdot 63$

Literatura $\cdot 67$ 


\section{Seznam slik in preglednic}

\section{Slike}

10.1 Primer iskanja po bazi patentov $\cdot 44$

10.2 Primer patenta $\cdot 46$

11.1 Spletna stran domačega spin-off podjetja Balder · 51

11.2 Oblike komercializacije novosti $\cdot 53$

11.3 Sejem inovacij v Kuvajtu · 55

12.1 Razvoj pametnega kolesa Flykly $\cdot 62$

\section{Preglednice}

10.1 Spremljanje tehnološkega razvoja $\cdot 42$ 


\section{Uvod}

V nekaj zadnjih letih se srečujemo s številnimi spremembami, ki zaznamujejo dogajanja v širšem - svetovnem in tudi ožjem - domačem gospodarskem in poslovnem okolju. Spremljamo lahko hiter razvoj znanosti, tehnologije, vključevanje informacijske tehnologije v vsakdanje delovanje in poslovanje podjetij, organizacij, inštitucij, držav in tudi posameznikov. Internet, mobilna telefonija in tudi druge informacijskokomunikacijske tehnologije (I K T) so svet dejansko povezale med seboj in ga naredile zelo odprtega, povezanega in prepoznavnega. Svetovno gospodarstvo se vedno bolj odpira in povezuje, na trge prihaja vedno več izdelkov in storitev $\mathrm{z}$ različnih koncev sveta, svetovna trgovina in mednarodno poslovanje pa pritegujeta in vključujeta vedno večje število podjetij iz mnogih držav sveta. Soočamo se z globalizacijo poslovanja, ki hitro spreminja strukturo in konkurenčnost svetovnega gospodarstva ter tudi razvoja posameznih držav v svetu. Svet še nikoli v svoji zgodovini ni bil tako blizu in povezan, kot je sedaj. To pa na drugi strani pomeni tudi večje število podjetij, ki ponujajo svoje izdelke in storitve svetovnim potrošnikom, ki imajo sedaj možnost izbire in odločanja o nakupu izdelkov in storitev ne samo v svoji bližnji trgovini za vogalom ali v svojem kraju, mestu ali državi bivanja, pač pa lahko s pomočjo uporabe napredne informacijsko-komunikacijske tehnologije izdelke in storitve naročajo in kupujejo tudi v svojem domu in to dejansko skoraj kjerkoli v svetu. Svet se vedno bolj odpira, povezuje in postaja skoraj enovit tržni prostor, kar povečuje možnosti in moč odločanja potrošnikov ter kupcev o nakupih in komercializaciji izdelkov ter storitev. Hkrati pa se tako krepita tudi konkurenca in konkurenčnost poslovanja, saj vedno več podjetij in organizacij ponuja vedno večje število izdelkov ter storitev, ki želijo najti poti do kupcev. V današnjem svetu sta čas in hitrost sprejemanja odločitev dva ključna elementa ter pogoja poslovne uspešnosti podjetij in tudi posameznikov. Prav zato, ker se moč odločanja o nakupovanju in komercializaciji blaga - izdelkov in storitev vedno intenzivneje koncentrira pri potrošnikih in kupcih, so znanja 
1 Uvod

o osnovnih procesih in vsebinah komercializacije ter poslovanja vedno bolj aktualna, še posebej za tiste udeležence - potrošnike in kupce, ki nimajo osnovne ekonomsko-poslovne izobrazbe in znanj.

izr. prof. dr. Dragan Kesič prof. dr. Borut Likar 


\section{Osnove delovanja gospodarstva \\ " Kaj je gospodarjenje \\ - Kaj je značilno za blagovno-denarno gospodarstvo \\ - Kaj je značilno za makroekonomijo in mikroekonomijo \\ - V kakšnih okoljih poslujejo podjetja}

Če želimo razumeti delovanje gospodarstva, se je potrebno seznaniti z osnovnimi zakonitostmi delovanja in poslovanja podjetij ter tudi delovanjem gospodarstva kot celote. Aktivnosti in delovanje obojega preučujeta ekonomija in management. Osnove delovanja podjetij običajno preučuje mikroekonomija, delovanje celotnega gospodarstva $v$ širšem, svetovnem, in tudi ožjem, domačem, gospodarskem okolju pa preučuje makroekonomija. Ena od najboljših opredelitev ekonomije je definicija znanega ekonomista, Nobelovega nagrajenca Paula Samuelsona, ki trdi naslednje (Samuelson 1995, 43): "Ekonomija raziskuje, kako ljudje in družba zaposlujejo redke resurse, ki imajo alternativno uporabo, s ciljem proizvajati različne dobrine in jih razdeliti med sedanjo in bodočo potrošnjo ter med posameznike in družbene skupine.«

Gospodarstvo oziroma gospodarjenje je sestavljeno iz več posameznih aktivnosti oziroma področij. Gospodarjenje je torej zavestna človekova dejavnost, s katero razporejamo dana omejena sredstva na različne možne uporabe s ciljem čim boljšega zadovoljevanja potreb.

Vsebina gospodarjenja vsebuje načelo gospodarjenja, ki ga lahko opredelimo kot:

1. želja po doseganju največjega možnega učinka z danimi sredstvi;

2. prizadevanje za doseganje največjega možnega učinka z najmanjšimi možnimi sredstvi.

Raziskave in razvoj vsebujejo vse potrebne aktivnosti za razvoj novih izdelkov in storitev, proizvodnja zajema vse potrebne procese in načine ustvarjanja izdelkov ter storitev. Izdelki in storitve nastajajo $\mathrm{v}$ proizvodnih enotah oziroma podjetjih - relativno majhen delež prihaja neposredno iz narave -, ki se med seboj razlikujejo po različnih dejavnostih, imenovanih tudi gospodarske panoge, po velikostih in obsegih 
poslovanja, po različnih organizacijah in tudi po uspešnosti svojega poslovanja. Menjava izdelkov in storitev poteka na trgih in poznamo tudi različne oblike trgov. Trgi se med seboj razlikujejo glede na vrsto izdelkov in storitev, s katerimi se trguje, glede na velikost in organizacijo, glede na različnost števila ponudnikov, torej neposrednih in tudi posrednih tekmecev oziroma konkurentov, ter tudi glede na geografsko lego, saj ločimo domače in tuje, svetovne trge. V naturalnem načinu gospodarjenja se izdelki neposredno porazdelijo $\mathrm{v}$ naravnih količinah $\mathrm{v}$ skladu $\mathrm{z}$ različnimi merili, torej menjave kot posebne faze $\mathrm{v}$ takem načinu gospodarjenja ne poznamo. V blagovno-denarnem gospodarstvu pa se ustvarjeni in proizvedeni izdelki ter storitve ponudijo in prodajajo na različnih trgih; v skladu $\mathrm{z}$ menjavo blago (izdelki ali storitve) za denar se nato ustvarjeni dohodek (prihodek) ustrezno razdeli. V fazi menjave oziroma naknadne delitve se tako odloča o vsebinah in vprašanjih razdelitve ustvarjenega bogastva, opredeljuje se razdelitev dohodka posameznih gospodarskih subjektov oziroma organizacij in podjetij. Smiselno primarna in tudi končna faza vsakega gospodarjenja, ki je nenazadnje končni in ključni cilj vsakega ustvarjanja idej, novih izdelkov in storitev, je potrošnja. Vsebine potrošnje lahko razdelimo na osebno potrošnjo, na naložbeno (investicijsko) oziroma reproduktivno, katere ključni cilj je nadaljnje ustvarjanje in razvoj novih izdelkov ter storitev oziroma ustrezna nadaljnja proizvodnja, in v končni fazi na potrošnjo družbe kot celote oziroma tudi trga kot celote in države, regije, ali skupne ekonomske asociacije (E U) kot celote. Poslovanje in tudi management torej preučujeta in ugotavljata zakonitosti in značilnosti, ki se odvijajo v posameznih sklopih in fazah oziroma vsebinskih procesih gospodarjenja ter poslovanja organizacij, podjetij in tudi držav.

Kot je bilo že poudarjeno, ločimo makroekonomijo in mikroekonomijo. Makroekonomija preučuje širše vidike gospodarjenja in poslovanja na ravni svetovnega gospodarstva, regionalnega in asociacijskega gospodarstva (E U) ter tudi celotnega nacionalnega gospodarstva, saj vključuje vse vidike in značilnosti vpliva države na potek in razvoj gospodarskoposlovnih aktivnosti.

Vključuje preučevanje ključnih agregatnih elementov, ki vplivajo na gospodarjenje in poslovanje, kot so razvoj in trendi svetovnega gospodarstva, strateška dogajanja v svetu, gibanje cen ključnih surovin na svetovnih trgih (nafta, rude, plin), gibanje valut posameznih držav, bruto družbeni proizvod držav in tudi nacionalnega gospodarstva, stopnja in raven zaposlenosti oziroma nezaposlenosti, količina denarja $\mathrm{v}$ obtoku, spreminjanje ravni cen (deflacija, inflacija) in gibanje plač. 
Makroekonomsko preučevanje vključuje tudi preučevanje vpliva države na potek in razvoj gospodarskih procesov. Država lahko s svojimi različnimi orodji - s politiko in strategijo zunanje trgovinske menjave, $s$ politiko opredeljevanja davkov in državnih prihodkov in izdatkov, z monetarno politiko, $\mathrm{z}$ dohodkovno in odhodkovno politiko, torej z gospodarsko politiko - pomembno vpliva, usmerja, do določene mere tudi prepoveduje delovanje in poslovanje podjetij ter organizacij. Mikroekonomija pa neposredno in primarno preučuje aktivnosti, specifičnosti in značilnosti delovanja podjetij ter organizacij.

Podjetje in organizacija je vsaka temeljna gospodarsko-poslovna aktivnost oziroma dejavnost, ki z razvojem, s proizvodnjo, predelavo, z dodelavo, s preoblikovanjem izdelkov in storitev ali tudi z drugimi aktivnostmi za potrošnike skuša skozi proces menjave doseči prodajo, prihodek in tudi dobiček. Podjetja in organizacije oskrbujejo potrošnike na različnih trgih (svetovnih, evropskih, regionalnih, nacionalnih in tudi drugih) $\mathrm{z}$ različnimi izdelki in storitvami. Izdelki so na primer prehranski izdelki, različni izdelki za široko potrošnjo, tekstilni izdelki, zdravila, avtomobili idr., storitve pa na primer bančne, zdravstvene, zavarovalniške, povezane s prevozom, preživljanjem prostega časa, potovanji, turizmom idr. Podjetja hkrati posameznikom, ki znajo poiskati pravo tržno priložnost, omogočajo, da obogatijo, zaposlenim v podjetjih pa zagotavljajo zaslužek za preživljanje družin. Uspešna podjetja in organizacije ter njihovi zaposleni plačujejo prispevke in davke, kar omogoča družbi, da gradi bolnišnice, šole, ceste in tudi drugo družbeno infrastrukturo. Gospodarstvo tako ustvarja dohodek in bogastvo, ki koristi vsem članom oziroma posameznikom v družbeni skupnosti.

Podjetja in organizacije poslujejo $\mathrm{v}$ zelo različnih poslovnih okoljih $\mathrm{z}$ različnimi vrednotami in vplivom na delovanje ter ravnanje ljudi in tudi vplivom na razvoj ter uspeh podjetij in podjetnikov. Za uspešno poslovanje in razvoj podjetij so ključni dejavniki, ki jih navajamo spodaj.

1. Podjetja poslujejo v globalnem okolju, za katerega sta značilni močna in naraščajoča mednarodna konkurenca in vse bolj prosta trgovina med državami. Tako se morajo tudi slovenska podjetja soočati z močno tujo konkurenco na domačem in tudi širšem trgu Evropske unije ter morajo vedno bolj iskati svoje priložnosti za poslovanje in razvoj na mednarodnih trgih. Mednarodno poslovanje je za slovenska podjetja ena od ključnih strategij za preživetje in nadaljnji razvoj.

2. Podjetja poslujejo v ekonomskem okolju, ki vpliva na položaj pod- 
jetij predvsem $\mathrm{z}$ delovanjem države in lahko pomembno vpliva na poslovna tveganja podjetij, na spodbujanje ali zaviranje aktivnosti podjetnikov, zlasti $z$ višino in načinom opredeljevanja davkov, s predpisanim postopkom ustanavljanja podjetij ter $\mathrm{z}$ vplivom na zakonodajno-pravno okolje poslovanja podjetij.

3. Podjetja poslujejo v tehnološkem okolju, ki predvsem vpliva na tehnično najučinkovitejši raziskovalno-razvojni proces, na inventivnost (nova odkritja) in inovativnost (nove rešitve in pristopi $\mathrm{v}$ proizvodnji, poslovanju, marketingu, prodaji in tudi drugih aktivnostih podjetja), na način in izvedbo proizvodnje, s tem pa tudi na stroškovno učinkovitost poslovanja. Danes vključevanje sodobne informacijsko-komunikacijske tehnologije (IKT) predstavlja bistveno konkurenčno prednost za delovanje in poslovanje podjetij, prav hitra in učinkovita uporaba informacij ter I K T je ključ za njihovo uspešno poslovanje.

4. Podjetja poslujejo v konkurenčnem okolju; v preteklosti nikoli ni bilo tako močne in ostre konkurence in konkurenčnosti (tekmovanja) med podjetji. Trg se nenehno spreminja, kupci si stalno želijo novih in novih izdelkov ter storitev, tekmeci na svetovne in nacionalne trge nenehno prinašajo nove, še boljše in bolj izpopolnjene izdelke ter storitve. Danes morajo podjetja tudi visoko kakovostne izdelke in storitve ponujati po konkurenčnih cenah. Zaradi visoko konkurenčnega poslovnega okolja lahko trdimo, da danes, še bolj pa bodo v bodoče podjetja poslovala v hiperkonkurenčnem okolju.

5. Podjetja poslujejo v marketinškem okolju, kjer se soočajo z marketinškimi aktivnostmi drugih podjetij, ki poudarjajo pomen lastnih izdelkov in storitev, nagovarjajo potencialne potrošnike za nakup, poudarjajo prednosti posameznih izdelkov in storitev ter usmerjajo svoje aktivnosti v določene ciljane dele trga.

6. Podjetja poslujejo v družbenem okolju, za katerega je značilna izrazita različnost, zato lahko govorimo o družbenem pluralizmu ali multikulturnem okolju; značilne so tudi zaznavne spremembe v demografskih gibanjih (stopnja prirastka prebivalstva, staranje prebivalstva, delež posameznih starostnih skupin v strukturi prebivalstva) in tudi spremembe v načinu življenja ter $\mathrm{v}$ sestavi družine (istospolna partnerstva, manjše število porok in otrok $\mathrm{v}$ družini).

Značilno za dogajanja v sodobnem svetu in tudi v poslovanju podjetij 
ter organizacij so stalne spremembe, ki se jim morajo podjetja in organizacije stalno prilagajati. To pa za vse udeležence poslovnega procesa (lastnike, vodstvo, zaposlene, dobavitelje, potrošnike) pomeni nenehno prilagajanje novonastalim pogojem poslovanja in tudi povečane konkurenčnosti, kar pa vsa podjetja in organizacije niso sposobni zagotavljati $\mathrm{v}$ enaki meri. Tudi to je eden od ključnih faktorjev uspešnega poslovanja, ki ločuje uspešna podjetja od manj uspešnih.

\section{Vprašanja za utrjevanje}

1. Kaj je temelj gospodarjenja?

2. Katere aktivnosti sestavljajo gospodarjenje?

3. Kaj je značilno za makroekonomijo?

4. Kaj je značilno za mikroekonomijo?

5. Kaj je značilno za delovanje podjetja in organizacije?

6. V kakšnih okoljih delujejo podjetja in organizacije?

7. Kaj je značilno za globalno okolje?

8. Kaj je značilno za ekonomsko okolje?

9. Kaj je značilno za tehnološko okolje?

10. Kaj je značilno za konkurenčno okolje?

11. Kaj je značilno za marketinško okolje?

12. Kaj je značilno za družbeno okolje?

13. Kaj zaznamuje delovanje in poslovanje podjetij ter organizacij v sodobnem svetu? 



\title{
3 Temeljno o delovanju in poslovanju podjetij
}

\author{
" Kaj je podjetje \\ - Kaj je firma podjetja \\ - Kako podjetje deluje in posluje \\ - Kakšni so cilji poslovanja podjetja \\ - S kakšnimi tveganji se sooča podjetje pri svojem \\ poslovanju \\ - Kaj predstavlja temeljni gospodarski proces
}

Podjetje je neka institucija - organizacija, ki kupuje ali najema temeljne proizvodne dejavnike (delo, zemljo) od drugih podjetij in jih uporabi $\mathrm{v}$ svoji proizvodnji ter poslovnih aktivnostih. Podjetje praviloma organizira vse potrebne vire s ciljem proizvodnje in prodaje dobrin (izdelkov in storitev), pri teh aktivnostih pa ga lahko vodi posameznik ali poslovodna ekipa (management). Podjetje ima vedno tudi svojega ustanovitelja in lastnika, lahko je ustanoviteljev in lastnikov podjetja tudi več. Glede na to ločimo tudi več pravnih oblik družb, ki jih v skladu $\mathrm{z}$ veljavno zakonodajo ustanavljajo lastniki, družbeniki in podjetniki; vsaka pravna oblika družbe ima tudi svoje podjetje.

Podjetje je osnovni skupek ljudi, sredstev (kapitala), idej, znanj, razvoja, tehnologije, izdelkov, storitev, aktivnosti marketinga, prodaje, nabave, temeljnih pravnih aktov, ki pogojuje ustanovitev in registracijo podjetja ter organizacije $\mathrm{z}$ namenom udejanjanja ključnih podjetniških idej in zamisli skozi proces poslovanja ter menjave na trgu s potrošniki in zadovoljevanja njihovih potreb ter s končnim ciljem ustvarjanja prihodka, dobička - denarnega toka in zagotavljanja nadaljnjega razvoja ter rasti podjetja in organizacije.

Podjetje je temeljna gospodarska enota, ki ima proizvodne dejavnike za razvoj in proizvodnjo dobrin (izdelkov in storitev) za trg, s čimer zadovoljuje potrebe drugih podjetij in potrošnikov. Podjetje ima svojo organizacijsko obliko in tudi firmo.

Firma podjetja je naziv, ime nekega podjetja oziroma gospodarske enote, $s$ katerim podjetje ali gospodarska enota deluje in nastopa, se 
predstavlja v svojem poslovanju in se $\mathrm{z}$ njim podpisuje. Firme podjetja so lahko zelo različne, na primer Krka Novo mesto, Nama Ljubljana, Lisca Sevnica, Peter Verbič, ključavničarstvo, Ljubljana.

Podjetje je tako kot pojem uporabljan dokaj široko, saj včasih s tem izrazom mislimo na firmo, včasih bolj na podjetje samo oziroma tudi katerega od njegovih obratov (razvoj in raziskave, kontrola, proizvodnja, nabava, marketing, prodaja, komerciala). Podjetje je tudi pravna oseba, ki v določeni organizacijski obliki proizvaja za trg na osnovi svojega poznavanja povpraševanja, ki ga skuša prepoznati s svojo raziskavo trga in ga tudi pospeševati z reklamo in s promocijskimi aktivnostmi. Zaradi tega ima podjetje praviloma organizirane vse potrebne poslovne funkcije, ki se dnevno soočajo $z$ vsemi poslovnimi tveganji, tako s tehničnotehnološkimi, ki so neposredno povezana $\mathrm{z}$ aktivnostmi raziskav in razvoja ter proizvodnje, kot tudi s širšim poslovnim tveganjem, ko se vršijo aktivnosti na trgu (marketing, nabava, prodaja, komercializacija).

Podjetje lahko lastniki z vložkom svojih sredstev (kapitala) ustanovijo $\mathrm{v}$ različnih pravnih oblikah in $\mathrm{v}$ skladu $\mathrm{z}$ veljavno zakonodajo. Tako poznamo različne pravne oblike podjetij (samostojni podjetnik - s.p., družba z neomejeno solidarno odgovornostjo - d. n. o., družba z omejeno odgovornostjo - d. o. o, delniška družba - d.d., komanditna delniška družba - k.d.d.), ki so tudi najpogostejše oblike družb, posedujočih podjetja. Lastniki - družbeniki, ki ustanavljajo družbo za doseganje načrtovanih poslovnih ciljev, morajo dobro poznati veljavno zakonodajo, ki predpisuje načine, pogoje in oblike ustanovitve možnih družb ter tudi njihovo registracijo v veljavni register podjetij. Vsako podjetje je registrirano pri odgovornem pravnem organu (sodišče), kar zagotavlja tudi njegovo verodostojnost in pravno zavezo (obligacijo) spoštovanja pravnih norm ter zakonodaje $v$ procesu delovanja in poslovanja vsakega podjetja. Gre predvsem zato, da družba in njeno podjetje v različnem obsegu, glede na obliko registrirane družbe, odgovarja za svoje obveznosti do drugih udeležencev $\mathrm{v}$ poslovnem procesu s ciljem korektnega in pravno zavezujočega poslovanja. Zato je pomembno, da udeleženci poslovnega procesa vedo, da poslujejo s podjetji, ki so zanesljiva, lastniško in organizacijsko urejena ter pravočasno in $\mathrm{v}$ dogovorjenih rokih izpolnjujejo svoje obveznosti. Vsako podjetje je možno preveriti glede zanesljivosti njegovega poslovanja. Na voljo so številne specializirane inštitucije (Kompass, Gvin, D \& B, Coface, Bisnode), ki aktivno spremljajo poslovanja podjetji in njihove spremembe ter na zahtevo naročnika izdajajo tako imenovane poslovne bonitete podjetij. $\mathrm{V}$ taki poslovni boniteti 
lahko naročnik pridobi vse ključne in temeljne podatke o delovanju in poslovanju nekega podjetja, predvsem pa lahko oceni njegovo poslovno sposobnost, solidnost in korektnost poslovanja ali neprimernost za poslovanje zaradi različnih razlogov (lastništvo, slabo poslovanje, prevelika zadolženost, neplačevanje obveznosti), kar lahko prepreči številne nadaljnje težave in zaplete pri poslovanju s takim podjetjem.

Cilji delovanja in poslovanja podjetja so zelo kompleksni in se lahko tudi spreminjajo. Vsako podjetje mora imeti opredeljeno svoje poslanstvo ali misijo, praviloma pa so njegovi ključni ekonomski cilji maksimiranje njegovih dobičkov, povečevanje prihodka in rasti, povečevanje tržnega deleža in tudi povečevanje konkurenčnosti njegovega poslovanja ter tudi tržne vrednosti podjetja. Vsi ti cilji so praviloma odvisni predvsem od štirih okoliščin, in sicer:

- ciljev lastnikov podjetja,

- razmerja moči in odnosov med lastniki ter neposrednim vodstvom podjetja,

- odnosov med neposrednim vodstvom in zaposlenimi v podjetju,

- tržnih pogojev poslovanja.

Za svoja razvoj in rast mora imeti podjetje jasno zastavljeno vizijo, konkretno opredeljene kratkoročne in dolgoročne cilje ter tudi izdelano oceno tveganj, $z$ več opcijskimi rešitvami v različno tveganih poslovnih situacijah.

Podjetja se pri svojem delovanju in poslovanju soočajo s številnimi tveganji, ki so sestavni del vsakega poslovanja; podjetja in organizacije skušajo tveganja v čim večji meri obvladovati in zmanjševati, a jih v celoti jih obvladati in odpraviti ni možno. Tveganja, ki so neposredno in posredno povezana $z$ delovanjem ter poslovanjem podjetij in organizacij, lahko razvrstimo v naslednje skupine:

- državna, politična in zakonodajna tveganja - vsa tveganja, ki izvirajo iz državne zakonodaje, spremembe vladnih politik in zakonodaj, politične stabilnosti ali nestabilnosti države, njenega ugleda in kreditnega stanja;

- finančna tveganja - vsa tveganja, ki so povezana s plačevanjem ali $z$ neplačevanjem, s finančno disciplino, spoštovanjem plačilnih rokov, spremembami valute in njene vrednosti, kratkoročno plačilno nesposobnostjo podjetij (nelikvidnostjo), dolgoročno plačilno nesposobnostjo podjetij (nesolventnostjo) ali prenehanjem delovanja in poslovanja podjetij (stečaj in likvidacija podjetja); 
- poslovna tveganja - vse, kar je povezano s poslovanjem podjetja (spoštovanje poslovnih dogovorov in dobavnih rokov, kadrovske zadeve);

- tehnološka tveganja - tveganja, povezana z izdelki in s storitvami, $\mathrm{z}$ uvedbo nove tehnologije, tveganja pri raziskavah in razvoju in zaradi zamud tehnološkega razvoja;

- ostala tveganja.

Podjetje se tveganjem v celoti ne more izogniti, mora pa delovati proaktivno in skušati delovati ter poslovati tako, da jih $\mathrm{v}$ največji možni meri odpravlja ali vsaj zmanjšuje. To lahko podjetja dosegajo na različne načine: s proaktivnim delovanjem in poslovanjem, spoštovanjem poslovnih dogovorov in pogodb, $\mathrm{z}$ aktivnim spremljanjem dogajanja in zakonodaje ter tudi s spremljanjem dogajanja na trgu in $\mathrm{v}$ svojem gospodarskem segmentu.

Za vsako podjetje je pomembna tudi organizacijska struktura podjetja, ki je praviloma odvisna od več elementov.

Organizacijska struktura podjetja je odvisna od več dejavnikov, in sicer:

- uporabljene tehnologije,

- velikosti podjetja,

- sprememb v okolju,

- strategije poslovanja,

- poslovne kulture,

- interesnih skupin.

Glede na obseg števila zaposlenih in ustvarjanje dohodka poznamo več vrst podjetij, in sicer:

- mikropodjetja (do 5 zaposlenih),

- mala podjetja (do 150 zaposlenih),

- srednje velika podjetja (od 150 do 500 zaposlenih),

- velika podjetja (nad 500 zaposlenih),

- mednarodna podjetja (delujejo in poslujejo v mednarodnem okolju),

- večnacionalna, tudi globalna podjetja (delujejo in poslujejo v več državah sveta).

Uspešnost poslovanja podjetja lahko merimo po različnih kazalnikih, najpogosteje pa se uporabljajo naslednji: 
- obseg prodaje in prihodka,

- produktivnost,

- ekonomičnost,

- rentabilnost,

- dobičkonosnost (prihodka, sredstev, kapitala).

Podjetja morajo pri svojem poslovanju $\mathrm{v}$ določenem gospodarskem okolju (tujem ali domačem) dosledno spoštovati veljavno zakonodajo, ki neposredno ali posredno vpliva na njihovo delovanje in poslovanje. Ključna je zakonodaja, ki se nanaša na poslovanje samega podjetja, plačevanje različnih obveznosti, davčnih prispevkov in drugih dajatev, ki jih predpisuje veljavna zakonodaja. Poleg tega je pomembna tudi zakonodaja, ki se nanaša na kapitalsko ustreznost podjetja, plačevanje obveznosti, zaposlovanje in tudi druge pravno-poslovne kategorije, ki ključno vplivajo na delovanje in poslovanje podjetij $\mathrm{v}$ gospodarskopravnem okolju.

Smisel ustanavljanja, delovanja in poslovanja podjetja je ustvarjanje pozitivnega ekonomskega (denarnega) učinka $\mathrm{v}$ določenem časovnem obdobju (kratkoročno, dolgoročno), ki ga podjetje in udeleženci v njegovem delovanju in poslovanju skozi različne poslovne aktivnosti preoblikujejo v različnih delovnih ter poslovnih fazah delovanja in poslovanja. Ključni pri tem so temeljni delovni in poslovni procesi v podjetju, in sicer načrtovanje izdelka in storitve, proizvodnja, prodaja (marketing) in pridobitev ustreznega plačila, kar podjetju omogoča zagotavljanje razvoja stalnega poslovnega kroga - ideja-izdelek-storitev-potrošnikdenar, to pa je smisel njegovega delovanja, poslovanja, razvoja ter rasti.

Proizvodnja je ena od temeljnih in ključnih poslovnih aktivnosti podjetja in proces, $v$ katerem nastajajo izdelki in storitve $z$ določeno dodano vrednostjo, ki jo podjetje $\mathrm{v}$ tem procesu dodaja glede na potrebne ostale sestavine, nabavljane iz drugih virov (sestavni deli, reprodukcijski material). Proizvodni dejavniki so vsi elementi, ki so potrebni za izdelavo materialnih dobrin (izdelkov). Glede na vlogo v proizvodnem procesu ločimo tri skupine proizvodnih dejavnikov, in sicer:

- delo,

- delovna sredstva,

- predmete dela.

Glede na prihodke, ki jih lastniki pridobijo v razdelitvi, ločimo:

- delo (dohodek, plača), 
- kapital (dohodek: dobiček oziroma obresti, če kapital posodimo),

- zemljišče (dohodek: renta).

$\mathrm{V}$ proizvodne dejavnike lahko uvrščamo tudi vsebine in znanja podjetništva, človeški kapital kot širši pojem od dela in tudi informacije, ki niso zastonj, saj se $\mathrm{z}$ njihovim aktualnim spremljanjem, zbiranjem in posredovanjem ukvarjajo posebna podjetja oziroma agencije.

Vseh proizvodnih dejavnikov je premalo, da bi z njimi lahko proizvedli toliko izdelkov in storitev, da bi z njimi lahko zadovoljili potrebe vseh potrošnikov. Zaradi tega se ekonomski problem podjetja in tudi družbe odslikava v relativni redkosti proizvodnih dejavnikov, pri čemer so ključna tri vprašanja, ki si jih mora zastavljati vsako podjetje:

1. Kaj in koliko proizvajati?

2. Kako proizvajati?

3. Za koga proizvajati?

Tako je za podjetje pomembna blagovna (izdelčna, storitvena) proizvodnja za prodajo oziroma menjavo $\mathrm{z}$ drugimi izdelki na trgu. Izdelke in storitve, ki so namenjeni menjavi na trgu, imenujemo blago. Blago je proizvod človekovega dela in tudi narave, ki ima uporabno in tudi menjalno vrednost na trgu. Uporabna vrednost blaga so vse koristne in uporabne lastnosti blaga, ki lahko zadovoljijo kupčeve potrebe. Menjalna vrednost blaga je količina drugega blaga, ki ga lahko na trgu dobimo za enoto blaga. Torej je to količinsko razmerje, v okviru katerega enoto blaga lahko zamenjamo za drugo blago. Če je na primer drugo blago, za katerega zamenjamo enoto našega blaga, denar, takšno menjalno vrednost imenujemo cena. Cena je tako denarni izraz vrednosti za neko blago, izdelek, storitev in opredeljuje tudi število denarnih enot, ki jih lahko v menjavi na trgu dobimo za enoto blaga.

Tako je temeljni gospodarski proces sestavljen iz treh naslednjih faz:

- faze proizvodnje,

- faze razdelitve,

- faze potrošnje.

Podjetja - proizvajalci v svojem proizvodnem procesu tako $v$ fazi razdelitve in potrošnje prejmejo denar, ki ga potem $v$ fazi menjave na trgu zamenjajo za tisto blago (količina, vrsta), ki ga potrebujejo pri svojem nadaljnjem poslovanju v svoji konkretni gospodarski panogi. Menjava je tako faza gospodarskega procesa, $v$ kateri se med blagovno produk- 
cijo izvede razdelitev proizvodnje (izdelki, storitve) in ki nastopa pred fazo potrošnje.

\section{Vprašanja za utrjevanje}

1. Kako lahko opredelimo pojem in vsebino podjetja?

2. Kaj je značilno za ustanovitev podjetja?

3. Kaj je firma podjetja in kaj predstavlja?

4. Kaj vse lahko predstavlja pojem podjetje?

5. Kakšni so cilji delovanja in poslovanja podjetja?

6. Kaj pogojuje cilje delovanja in poslovanja podjetja?

7. Kaj je pomembno za razvoj in rast podjetja?

8. Kaj je značilno za tveganja, s katerimi se sooča podjetje?

9. Kakšna tveganja poznamo, kaj je značilno za njih?

10. Kako podjetje lahko obvladuje tveganja?

11. Kaj sestavlja organizacijsko strukturo podjetja?

12. Kakšne vrste podjetij poznamo?

13. Kako lahko merimo uspešnost poslovanja podjetja?

14. Kaj je poslovna boniteta podjetja?

15. Kako zakonodaja vpliva na delovanje in poslovanje podjetij?

16. Kaj je ključni smisel delovanja in poslovanja podjetja?

17. Kaj je značilno za proizvodnjo?

18. Kateri so ključni proizvodni dejavniki?

19. Katera temeljna tri vprašanja si zastavlja vsako podjetje?

20. Kaj je blago?

21. Kaj je trg?

22. Kaj je uporabna vrednost blaga?

23. Kaj je cena?

24. Kaj sestavlja temeljni gospodarski proces? 



\title{
4 Osnovno o trgu in tržni strukturi
}

\author{
- Kaj je trg in kakšne vrste trgov poznamo \\ - Kaj je značilno za gospodarsko panogo \\ - Kaj je konkurenca in kaj je zanjo značilno \\ - Kaj je popolna konkurenčna ponudba
}

$\operatorname{Trg}$ lahko opredelimo kot neposredni stik in proces, ki poteka med ponudniki (prodajalci) in povpraševalci (kupci) in v katerem se odloča o kupljenem oziroma prodanem blagu določene gospodarske panoge (izdelki, storitve) ter o njegovih temeljnih pogojih menjave (količina, cena, kakovost, načini plačila in tudi drugi bistveni elementi nakupa in prodaje).

Gospodarska panoga je del gospodarstva, ki ga tvorijo podjetja, ki proizvajajo in na trgu ponujajo skupine izdelkov ter storitev. Tako poznamo številne gospodarske panoge, ki sestavljajo celotno gospodarsko strukturo nekega gospodarstva, na primer panogo trgovine, panogo tekstilne industrije, panogo kemijske industrije, panogo kovinske industrije, panogo gradbeništva, panogo prehranske industrije, panogo avtomobilske industrije itd.

V poslovni praksi se srečujemo $\mathrm{z}$ mnogimi vrstami trgov, in sicer poznamo: živilski trg, trg zlata, trg nafte, trg surovin, trg avtomobilov, svetovni trg, evropski trg, trg evropske skupnosti (E U), regionalni trg, nacionalni trg itd.

Bistvena, ključna in temeljna značilnost delovanja vsakega trga je konkurenca, ki poteka med kupci in tudi prodajalci. S konkurenco poskušajo kupci in tudi prodajalci ne določen način reševati nasprotje interesov. Kupci namreč želijo kupovati izdelke in storitve po čim nižjih cenah, prodajalci pa prodajati izdelke in storite čim dražje, ob predpostavki, da se oboji skušajo obnašati čim racionalneje. Konkurenca namreč na trgu poteka na različne načine. Kupci si lahko medsebojno konkurirajo tako, da, če je blaga (izdelkov, storitev) premalo, običajno ponudijo višje plačilo, prodajalci pa običajno mesedbojno konkurirajo tako, da znižajo ceno s ciljem, da bi lahko svoje blago (izdelke, storitve) kupcem tudi prodali. $\mathrm{V}$ obeh primerih se konkurenca usmerja predvsem $\mathrm{v}$ 
cenovno kategorijo, zato lahko govorimo o cenovni konkurenci. Na trgu se odvija tudi necenovna konkurenca, ki jo sestavljajo elementi kakovosti blaga ter posamezni elementi marketinških aktivnosti, kot sta oglaševanje in pospeševanje prodaje (reklama, nudenje servisnih storitev, različna svetovanja, montaže, prilagajanje izdelka in storitve individualnim potrebam kupca).

Stopnja konkurence je glede na različne trge zelo različna. Praviloma določa obliko in vsebino trga ter tudi njegovo tržno strukturo. Ključni vsebinski dejavniki, ki opredeljujejo tržno strukturo posameznega trga, so naslednji:

1. število kupcev in prodajalcev na trgu,

2. stopnja razlikovanja izdelkov in storitev,

3. stopnja mobilnosti proizvodnih dejavnikov.

Število kupcev in prodajalcev ter obseg nakupa in prodaje obeh skupin udeležencev medsebojne menjave na trgu se lahko na različnih trgih med seboj močno razlikuje. Če je na nekem trgu en sam prodajalec, kupcev pa veliko, tržno strukturo imenujemo monopol oziroma trg imenujemo trg monopolne ponudbe. Lahko imamo na nekem trgu samo nekaj velikih proizvajalcev (na primer proizvajalci zdravil), na drugi strani pa imamo veliko kupcev in lahko govorimo o trgu tako imenovane oligopolne ponudbe. Lahko pa imamo na trgu veliko prodajalcev in tudi veliko kupcev - tedaj govorimo o trgu popolne konkurenčne ponudbe.

Stopnja razlikovanja izdelkov in storitev opredeljuje, v kakšni meri lahko kupci razlikujejo med izdelki in storitvami. Če so izdelki in storitve popolnoma enaki pri vseh proizvajalcih in zato kupci ne morejo razlikovati med njimi, torej jim je vseeno, od katerega proizvajalca kupijo izdelke in storitve, lahko rečemo, da so izdelki in storitve homogeni oziroma so popolni substituti. Tako so v pogledu kupcev izdelki in storitve vseh proizvajalcev na trgu v celoti enakovredni - takšnih izdelkov in storitev pa je na trgu relativno malo. Običajno kupci razlikujejo različne blagovne znamke izdelkov in storitev, ki so last različnih proizvodnih podjetij (na primer prehranski izdelki, kozmetični izdelki, gospodinjski aparati itd.).

Stopnja mobilnosti proizvodnih dejavnikov opredeljuje, v kakšnem obsegu je možno preseliti proizvodne dejavnike iz posameznih gospodarskih panog, kjer se cena izdelkov znižuje in imajo posamezni proizvajalci izgube, $v$ tiste panoge, kjer cena teh izdelkov in storitev narašča ter vsaj nekaj časa omogoča dokaj visoke dobičke. Če so ovire za seli- 
tev ključnih faktorjev nizke ali jih sploh ni, so proizvodni dejavniki prosto gibljivi. Lahko pa nastopijo tudi ovire, ki so lahko naravne (tehnologija, potrebna sredstva - kapital) ali druge ovire (zakonodajni predpisi države, potrebna dovoljenja, licence, patenti idr.), kar pomeni, da je premik proizvodnih dejavnikov zelo težak in omejen.

Za popolno konkurenčno ponudbo je tako značilno, da tržne zakonitosti delujejo neovirano (brez vpliva države in tvorjenja monopolov) ter le na osnovi ponudbe in povpraševanja ter spreminjanja cene izdelkov in storitev. Tržne zakonitosti poslovanja delujejo v pogojih popolne konkurence v popolni obliki, zato so tudi njeni rezultati ocenjeni kot idealni in najboljši. Popolno konkurenco lahko opredelimo tudi z vsebino dejavnikov tržne strukture, in sicer velja:

- prisotno je veliko število prodajalcev in kupcev; vsak kupec (prodajalec) kupuje (prodaja) relativno majhno količino blaga v primerjavi s celotno količino blaga na celotnem trgu, zato sam ne more odločujoče vplivati na ceno izdelkov in storitev; cena je na trgu znana in vsak kupec (prodajalec) se ji prilagaja, odloča pa se, kakšno količino blaga je pri obstoječi ceni na trgu pripravljen kupiti (prodati) - to značilnost popolne konkurence imenujemo tudi čista konkurenca;

- izdelki in storitve na trgu so homogeni, kupci običajno ne razlikujejo med proizvajalci, izdelki in storitve so popolni substituti (zamenjava) za izdelke ter storitve drugih proizvajalcev; kupci običajno kupujejo izdelke in storitve pri tistem ponudniku, ki ponudi najnižjo ceno; če bo ponudnik poskušal zvišati ceno, bodo kupci odšli in kupovali drugje;

- značilna je tudi popolna mobilnost proizvodnih dejavnikov - to je prosta konkurenca; torej ni prisotnih nobenih naravnih ali tudi drugih ovir za selitev dejavnikov v tiste gospodarske panoge, kjer se cene izdelkov in storitev zvišujejo ter nudijo višje zaslužke (dobičke) za izstopanje iz panog z izgubami.

\section{Vprašanja za utrjevanje}

1. Kako lahko opredelimo pojem trga?

2. Kakšne vrste trgov poznamo?

3. Kako lahko opredelimo pojem gospodarske panoge?

4. Naštejte nekaj gospodarskih panog in njihove značilnosti poslovanja.

5. Kako bi lahko opredelili pojem konkurence? 
4 Osnovno o trgu in tržni strukturi

6. Kaj je cenovna konkurenca?

7. Kaj je značilno za necenovno konkurenco?

8. Kaj opredeljuje tržno strukturo?

9. Kaj je značilno za monopolno ponudbo?

10. Kaj je značilno za oligopolno ponudbo?

11. Kaj je značilno za popolno konkurenčno ponudbo?

12. Kaj opredeljuje stopnja razlikovanja izdelkov in storitev?

13. Kaj opredeljuje stopnja mobilnosti proizvodnih dejavnikov?

14. Kaj je značilno za popolno konkurenčno ponudbo?

15. Kaj je čista konkurenca?

16. Kaj je prosta konkurenca? 


\section{Povpraševanje in ponudba}

- Kaj je ponudba in kaj je povpraševanje

- Kaj je značilno za učinek realnega dohodka

- Kaj je značilno za temeljne kategorije poslovanja podjetja

- Kaj predstavlja cena izdelka in storitve

- Kaj je značilno za tržno gospodarstvo

Vse različne sile, ki na nekem trgu delujejo v različnih aktivnostih kupcev, lahko opredelimo kot povpraševanje. Vse ključne elemente, ki neposredno vplivajo nanj, lahko razvrstimo v naslednje štiri skupine:

1. cena izdelkov in storitev, ki se kupuje,

2. cene drugih izdelkov in storitev, ki so neposredno primerljivi ali možno zamenljivi izdelki in storitve (substituti),

3. razpoložljivi dohodek potrošnika,

4. skupna elementov, kamor uvrščamo potrošnikov okus, potrebe, želje, druge možnosti in pogoje nakupa (potrošnikove preference).

Tako lahko za razumevanje delovanja trga opredelimo zakon ponudbe in povpraševanja, ki pravi, da se količina in cena blaga (izdelkov, storitev) spreminjata $v$ obratni smeri ob predpostavki nespremenjenih vseh ostalih faktorjev. To pomeni, da če ceno zvišamo, se obseg povpraševanja zmanjša.

Nasprotno velja pri znižanju cene: tam se namreč obseg povpraševanja poveča zaradi dveh učinkov, in sicer učinka realnega dohodka in učinka zamenjave. Ker se cena zniža, se kupčev realni dohodek poveča, torej lahko kupi več teh in tudi drugih izdelkov ter storitev - to je učinek realnega dohodka. Zaradi znižanja cene pa so ti izdelki in storitve postali tudi relativno cenejši kot neposredno zamenljivi izdelki in storitve, zato bo kupec prešel od zamenljivih izdelkov in storitev na te izdelke in storitve; to hkrati tudi pomeni, da se bo povpraševanje po teh izdelkih in storitvah zaradi učinka zamenjave še povečalo. 
Povpraševanje se lahko spremeni, če se spremeni katerikoli njegov ključni element, razen cene izdelkov in storitev. Povpraševanje se tako lahko poveča, če se:

- poveča potrošnikov dohodek,

- povečajo skupni elementi, kamor uvrščamo potrošnikov okus, potrebe, želje, druge možnosti in pogoje nakupa (potrošnikove preference),

- povečajo cene drugih izdelkov in storitev, ki so neposredno primerljivi ali možno zamenljivi izdelki in storitve (substituti),

- znižajo cene dopolnjujočih se izdelkov in storitev.

Vse različne sile, ki na nekem trgu delujejo $v$ različnih aktivnostih ponudnikov (prodajalcev), lahko opredelimo kot ponudbo. Na ponudbo, za razliko od povpraševanja, vplivajo zelo različni elementi. Nekaj ključnih elementov, ki neposredno vplivajo na ponudbo:

- cena izdelkov in storitev v ponudbi,

- uporabljena tehnologija v proizvodnji izdelkov in storitev,

- obstoječe zaloge izdelkov,

- cene proizvodnih faktorjev (energija, surovine, polizdelki),

- pričakovano gibanje cene izdelkov in storitev v prihodnosti,

- drugi naravni pogoji,

- gibanje cen energije, surovin in polizdelkov na svetovnem trgu,

- cene drugih vrst izdelkov in storitev, ki bi jih lahko proizvajalci tudi proizvajali, in tudi njihovi dobički,

- potreba ponudnika, da pridobi razpoložljiva (likvidna) sredstva za nadaljevanje proizvodnje in poslovanja,

- vsi ostali faktorji.

Celotni prihodek ponudnika skupaj s celotnimi stroški poslovanja tako opredeljuje ponudnikov dobiček, in sicer:

dobiček = celotni prihodek - celotni stroški, oziroma $\mathrm{D}=\mathrm{CP}-\mathrm{CS}$.

Če je prihodek enak celotnim stroškom, lahko rečemo, da podjetje posluje mejno, saj tako nima izgube, vendar tudi ne ustvarja nobenega dobička. Stanje, v katerem ni ne izgube ne dobička, ne more trajati dolgo, saj mora podjetje znati ukrepati in sprejeti take odločitve, ki ga lahko vodijo do načrtovanega dobička. Če podjetje ustvarja izgubo, torej če so celotni stroški poslovanja večji od celotnega prihodka, s tem izgublja 
tudi svoja sredstva (kapital), zato takega stanja ne more dolgo zdržati. Zato mora tako podjetje natančno in skrbno pretehtati ter preučiti svoje izdelke in storitve, proizvodne zmožnosti, tržne okoliščine in sprejeti določene ukrepe s ciljem izboljšanja svojega poslovanja. Torej je konkurenca zelo dinamičen tržni proces, ki ima svoje pozitivne in tudi negativne posledice.

Cena izdelkov in storitev v ponudbi je eden od ključnih elementov ponudbe, a so $\mathrm{v}$ celotni strukturi ponudbe pomembni tudi proizvodni stroški. Ponudba je namreč še bolj kot povpraševanje odvisna od časa, ki ga imajo na voljo proizvajalci, da se lahko prilagodijo stalno spreminjajočim se tržnim pogojem in razmeram. Če se na primer v nekem trenutku cena izdelka in storitve poveča, bo prvi odgovor ponudnika povečanje prodaje iz obstoječih zalog, zato se bo obseg ponudbe povečal. V kratkem času namreč povečanje ponudbe zaradi večje proizvodnje še ni možno. $\mathrm{V}$ daljšem časovnem obdobju pa bodo podjetja $\mathrm{v}$ panogi povečala proizvodnjo, saj višja cena omogoča pokrivanje višjih stroškov na enoto izdelka, ki so praviloma pogojeni $z$ večjo proizvodnjo. V sami panogi pa se lahko pojavijo tudi nova podjetja s praviloma višjimi proizvodnimi stroški. Tako se praviloma pri višji ceni poveča obseg proizvodnje $\mathrm{v}$ določeni gospodarski panogi.

Poznamo tudi pojem tržnega ravnovesja. To je stanje na trgu, kjer je obseg ponudbe izdelkov in storitev enak obsegu povpraševanja pri določenem nivoju tržne cene izdelka in storitve.

Vsekakor pa so ključni elementi tržnega mehanizma in tržnega delovanja, poslovanja podjetij in organizacij svoboda poslovnega odločanja, privatna lastnina in zasebni samointeres tržnih subjektov - podjetij, ki poslujejo na trgu. Podjetja, njihovi lastniki in vodstvo (management) tako $\mathrm{v}$ celoti prevzemajo vsa tveganja za slabe odločitve in si na drugi strani tudi prisvajajo dobičke za dobre poslovne odločitve ter ustvarjene dobičke. Zato je pri tem pomembno pravilno oceniti trenutne, še bolj pa bodoče tržne razmere in pogoje poslovanja na trgu ter sprejeti primerne odločitve. Trg je tako prostor tekmovanja med podjetji, med podjetji in potrošniki, znotraj podjetja pa so pomembni odnosi med lastniki, vodstvom (managementom) in zaposlenimi, ki so ključni dejavniki ustvarjanja dobrih poslovnih dosežkov podjetja. Trg ima tako zelo pomembne lastnosti, da izenačuje tržne subjekte, da pri razviti konkurenci odpravlja različne privilegije in nagrajuje učinkovite, inovativne, iznajdljive ter uspešne ponudnike (višji dobički ob znižanju stroškov), hkrati pa tudi izloča neuspešne, ki morajo sami prevzeti krivdo za lastno neu- 


\section{Povpraševanje in ponudba}

činkovitost in neuspešnost. Tržno gospodarstvo je prav zaradi tega zelo pragmatično, podjetja se tako stalno učijo iz poslovnih izkušenj, morajo hitro uvajati in uporabljati različne podjetniške, lastninske, pravne, finančne, tehnološke, marketinške, prodajne, informacijske in tudi druge aktivnosti ter rešitve. Prednost trga je v poslovni svobodi, ustvarjalnosti in prevzemanju tveganja za lastne uspehe ter tudi neuspehe na trgu. Tržno gospodarstvo je učeče in razvijajoče se gospodarstvo, spodbuja podjetništvo in njegove različne oblike ter tudi dokaj hitro reagira na spremembe oziroma spremenjene pogoje in okoliščine poslovanja.

\section{Vprašanja za utrjevanje}

1. Kaj ključno vpliva na povpraševanje?

2. Kaj je značilno za zakon ponudbe in povpraševanja?

3. Kaj vse vpliva na povpraševanje?

4. Kaj vse vpliva na ponudbo?

5. Kaj je dobiček?

6. Kako lahko podjetje upravlja svoj dobiček?

7. Kakšno je lahko razmerje cene izdelka in storitve v primerjavi s proizvodnimi stroški?

8. Kaj opredeljuje pojem tržnega ravnovesja?

9. Kaj je značilno za delovanje trga?

10. Kateri so temeljni elementi tržnega mehanizma in tržnega delovanja?

11. Kaj zaznamuje tržno gospodarstvo? 


\title{
6 Vloga izdelka in storitve v komercializaciji
}

\author{
- Kaj je značilno za izdelek in storitev \\ - Kako podjetje upravlja izdelek in storitev \\ - Kaj je zadovoljstvo potrošnikov \\ - Kaj je zvestoba potrošnikov
}

Izdelek in storitev, ki ju podjetje ponuja potrošnikom na trgu, je temeljni element tržnega uspeha in komercializacije podjetja. Načrtovanju, ustvarjanju, razvoju, proizvodnji, marketingu in prodaji ter tudi poprodajnim aktivnostim mora zato vsako podjetje posvečati maksimalno potrebno pozornost. Izdelek in storitev sta tudi temeljna gradnika poslovne strategije vsakega podjetja, njegovega razvoja in rasti ter doseganja konkurenčne prednosti ali tudi neuspeha na trgu. Podjetje lahko izdelke načrtuje in razvija samo v okviru lastnih raziskovalno-razvojnih aktivnosti ali jih tudi pridobi na trgu v okviru različnih poslovnih sporazumov, poslovnih dogovorov in pogodb (licenca, blagovne znamke, druge oblike sodelovanja) s potencialnimi partnerji.

Podjetje mora znati upravljati izdelek in storitev s ciljem doseganja uspešnih prodajnih rezultatov na trgu (obseg prodaje, tržni delež) in tudi smiselnega upravljanja svoje življenjske krivulje, ki zajema fazo načrtovanja, uvajanja na trg, doseganja rasti prodaje, doseganja vrha prodaje in padca prodaje. Posamezne gospodarske panoge se med seboj razlikujejo glede na izdelke in storitve, ki jih proizvajajo in ponujajo na trgu (izdelki in storitve za široko potrošnjo, preživljanje prostega časa, potovanja, turizem bančništvo, telefonija), zato mora vsako podjetje ponudbo svojih izdelkov in storitev znati prilagoditi ciljani potrošniški skupini na trgu, ki povprašuje pa določenih izdelkih in storitvah. Sodobno gospodarsko poslovanje zaznamuje predvsem hiter obseg in rast trga storitev, kar je pogojeno $\mathrm{z}$ sodobnim načinom življenja in preživljanja prostega časa (bančništvo, mobilna telefonija, potovanja, turizem, hitra prehrana), ta pa omogoča komercializacijo nekaterih novih izdelkov in storitev na trgu.

Za podjetje je pomembno, da pravočasno zazna potrebo na trgu po do- 
ločenem izdelku in storitvi ter da lahko prilagodi svoje poslovne aktivnosti tako, da potrošnikom lahko ob pravem času in pred konkurenco ter s pravimi komercialnimi pogoji (cena, kakovost, dobava in tudi ostalo) zagotovi dosegljivost tega izdelka in storitve na trgu. Seveda mora podjetje pozorno spremljati tudi izdelke in storitve, ki jih na trgu ponujajo konkurenčna podjetja.

Tako podjetje lahko sledi svoji poslovni strategiji uspešnega zadovoljevanja potreb potrošnikov in si gradi tudi dolgoročno poslovno sodelovanje s svojimi potrošniki, kar je še posebej pomembno $\mathrm{v}$ pogojih močne konkurence. Zadovoljstvo potrošnikov namreč ni več zadosten faktor uspeha podjetja, za njegovo dolgoročno uspešno poslovanje in razvoj ter tudi rast je namreč ključnega pomena zvestoba potrošnikov, ki podjetju omogoča dolgoročno uspešno poslovanje. Načrtovanje ustrezne politike izdelka je pogojeno $\mathrm{z}$ gospodarsko panogo, $\mathrm{v}$ kateri podjetje posluje, natančnimi in stalnimi spremljanji dogajanja na trgu v cilju pravočasnega prepoznavanja potreb in želja kupcev ter ponujanja takih izdelkov in storitev, ki bodo lahko prepoznane potrebe in želje uspešno zadovoljili. Pri tem in tudi ob izvajanju marketinških aktivnosti je za dolgoročno uspešno poslovanje podjetja pomembno, da izdelke in storitve na trgu ponudi $\mathrm{z}$ lastno identiteto in izbrano blagovno znamko, ki bo zagotavljala razlikovanje od ostale ponudbe na trgu in hkrati tudi graditev ter utrjevanje lastne identitete podjetja.

\section{Vprašanja za utrjevanje}

1. Kakšen je pomen izdelka in storitve za podjetje?

2. Kaj pomeni upravljanje izdelka in storitve za podjetje?

3. Kaj mora opazovati in spremljati podjetje na trgu?

4. Kaj pomeni zadovoljstvo potrošnikov v zvezi z izdelkom in s storitvijo podjetja?

5. Zakaj je za podjetje pomembna zvestoba potrošnikov?

6. Kakšno vlogo ima za podjetje blagovna znamka izdelka in storitve? 


\section{Marketing in komercializacija \\ " Kaj je marketing \\ - Kaj je značilno za marketinško delovanje podjetij \\ - Kaj je značilno za blagovno znamko}

Marketing v sodobnem poslovanju podjetij zaradi velike konkurence igra zelo pomembno, lahko bi rekli $\mathrm{v}$ mnogih gospodarskih panogah celo odločujočo vlogo. Gre za skupek aktivnosti kvalitetnega obvladovanja trga. Podjetje v marketinških aktivnostih upošteva ključne sestavne elemente, in sicer izdelek, njegovo ceno, trg in potrebo po tržnem komuniciranju ter sporočanju potrošnikom, kaj jim lahko podjetje ponudi in pod kakšnimi pogoji. Prva marketinška aktivnost podjetja je dobro raziskati trg in potrebe potrošnikov, jih preučiti in na osnovi tega razviti, pripraviti, proizvesti ter trgu ponuditi take izdelke in storitve, ki bodo lahko izpolnili pričakovanja, potrebe in želje potrošnikov. V skladu s tem podjetje izvaja marketinško strategijo za izdelek in storitev ter uporablja ustrezne vsebine marketinškega komuniciranja, s katerimi nagovarja in prepričuje potrošnike za nakup izdelkov ter storitev podjetja.

Za ustrezno marketinško delovanje sta pomembna tudi nadzor in potrebna korekcija marketinške strategije, ki mora ciljano doseči opredeljen del trga potrošnikov, na katerega se usmerja podjetje s svojimi marketinškimi aktivnostmi. Zato mora podjetje delovati marketinško ciljano, usmerjeno $v$ določen del trga in tudi primerno predstaviti svoj izdelek in storitev potrošnikom. Dolgoročno pomembno je, da podjetje lahko doseže zaznavno prepoznavnost svojih izdelkov in storitev pri potrošnikih, kar lahko zagotavlja v načrtnem procesu upravljanja lastnih blagovnih znamk, ki predstavljajo pomembno konkurenčno prednost in tudi premoženje podjetja.

\section{Vprašanja za utrjevanje}

1. Kaj je marketing?

2. Zakaj je marketing pomemben za poslovanje podjetja? 
7 Marketing in komercializacija

3. Katere so ključne vsebine marketinga?

4. Kako mora delovati podjetje $\mathrm{v}$ marketingu?

5. Kakšna je vloga blagovne znamke v marketingu podjetja? 


\title{
8 Osnovne aktivnosti komercializacije
}

\author{
- Kaj je značilno za komercialne aktivnosti \\ - Kateri so temeljni in ključni elementi poslovanja \\ - Kaj je značilno za poslovanje podjetja
}

Podjetje kot ponudnik svoje izdelke in storitve ponuja povpraševalcem - potrošnikom na trgu. Potrošniki se običajno, preden se odločijo za nakup, pozanimajo o temeljnih prodajnih in nakupnih pogojih, kot so cena, količina, kakovost, pogoji dobave in tudi plačila, ki so temeljni in osnovni pogoji sklenitve poslovnega dogovora oziroma nakupa in prodaje. Pri tem gre hkrati za pravni in tudi poslovni vidik sklenitve poslovnega razmerja, saj prodaja in nakup izdelka ter storitve hkrati pomeni tudi odplačni prenos lastninske pravice od prodajalca na kupca. Prodajalcu $\mathrm{z}$ dejanjem prodaje preneha lastninska pravica nad izdelkom in storitvijo, kupec pa prav tako lastninsko pravico $z$ dejanjem nakupa pridobi. Gre torej za tržno menjavo blaga - izdelkov in storitev - za denar. Celovit poslovni in tudi pravni vidik sklenitve prodajne oziroma komercialne aktivnosti je v celoti sklenjen ter zaključen tedaj, ko prodajalec $\mathrm{s}$ strani kupca pridobi v celoti predvideno kupnino v denarju. Če prodajalec kupcu blago samo izroči, pri tem pa ne pridobi plačila v obliki denarja ali morda drugega dogovorjenega blaga, ne moremo govoriti o celoviti in dokončni prodaji oziroma izpolnjevanju vseh komercialnih pogojev poslovanja.

Zato je pri dogovarjanju, sklepanju in izvrševanju poslovnih dogovorov in komercializaciji potrebno upoštevati naslednje ključne in temeljne elemente poslovanja:

- osnovne značilnosti izdelka in storitve, kot so cena, količina, kakovost,

- osnovno enoto mere (ks, m, kg, g, l),

- tehnološke značilnosti izdelka in storitve (tehnološka skladnost z zahtevanimi standardi, uporabnost, funkcionalnost),

- dobavljivost in pogoje dobave za izdelek ter storitev, 
- druge pogoje poslovanja za izdelek in storitev (garancijska doba, zagotavljanje nadomestnih delov),

- možne poprodajne storitve,

- plačilne pogoje,

- načine plačila,

- roke plačila.

Prodajalec mora kupca natančno, pravilno in v celoti seznaniti z vsemi ključnimi elementi poslovanja, ki jih mora kupec preučiti in na podlagi sprejete odločitve o ustreznosti vseh ponujenih pogojev sprejeti končno odločitev o nakupu oziroma o nenakupu določenega izdelka in storitve. Podjetja na trgu za svoje izdelke in storitve nudijo različne temeljne pogoje poslovanja, kupci so tisti, ki pogoje poslovanja posameznih podjetij, še posebej tistih, ki poslujejo v identičnih gospodarskih panogah, praviloma natančno pregledajo in jih tudi neposredno primerjajo med seboj. Na osnovi sprejete končne ocene o najboljši in najustreznejši ponudbi kupci sprejmejo tudi končno odločitev o izboru najustreznejšega ponudnika, s katerim kupec potem tudi sklene prodajno-nakupno pogodbo oziroma izvrši nakup.

Pri poslovanju podjetja s kupci - podjetji (medorganizacijsko poslovanje med podjetji) se praviloma poleg potrjevanja naročila sklepajo tudi pisne pogodbe, kjer se natančno opredelijo vsi ključni elementi poslovanja. Plačilo med podjetjem - ponudnikom in podjetjem - kupcem praviloma poteka preko poslovnih bank v obliki nakazil, ki so lahko tudi zavarovana $z$ različnimi možnimi načini (menice, bančne garancije, vrednotnice). Podjetja se lahko dogovorijo tudi za plačilo v naprej oziroma avansno plačilo. V mednarodnem poslovanju podjetij pa se uporabljajo tudi drugi, mednarodno dogovorjeni načini plačevanja (plačilo vnaprej - avansno plačilo, plačilo s čeki, dokumentarni inkaso, dokumentarni akreditiv, bančna garancija)

Pri poslovanju podjetja s kupci - fizičnimi osebami pa praviloma podjetje kupcu izda račun o nakupu izdelka in storitve, ki je tudi temeljni dokument poslovanja. Poleg tega se običajno kupcu posredujejo tudi drugi potrebni dokumenti, in sicer navodila za uporabo, različne tehnične specifikacije, izjava o garanciji in garancijski dobi ter tudi drugi dokumenti glede na konkretni izdelek in storitev.

\section{Vprašanja za utrjevanje}

1. Kaj je temelj komercialne aktivnosti? 
Osnovne aktivnosti komercializacije $\mid 8$

2. Kateri so ključni elementi poslovanja?

3. S čim mora prodajalec seznaniti kupca?

4. Kaj je značilno za poslovanje podjetja s kupci - podjetji?

5. Kaj je značilno za plačila v mednarodnem poslovanju?

6. Kaj je značilno za poslovanje podjetja s kupci - fizičnimi osebami? 



\section{Sodobni načini komercializacije (e-poslovanje)}

- Kakšna je vloga sodobne informacijsko-komunikacijske tehnologije v poslovanju

- Kaj je e-poslovanje

- Kakšne vrste e-poslovanja poznamo

- Kakšne so najpomembnejše aktivnosti e-poslovanja in komercializacije preko interneta

Izjemno hiter razvoj sodobne informacijsko-komunikacijske tehnologije (I K T) potrošnikom in tudi podjetjem z omogoča zelo hitro dosegljivost in primerljivost informacij ter podatkov o podjetjih, izdelkih in storitvah praktično po celem svetu. To pomeni, da imajo podjetja in tudi potrošniki možnost nenehnega preverjanja in primerjanja ponudbe izdelkov, storitev in pogojev komercializacije, izbiranja najboljših ponudb in najboljših pogojev poslovanja ter komercializacije. To za podjetja predstavlja nov način pristopa $\mathrm{k}$ poslovnim aktivnostim in komercializaciji. V tem kontekstu govorimo o hitrem razvoju komercializacije in poslovanja v obliki elektronskega oziroma e-poslovanja.

E-poslovanje bi lahko opredelili kot vse poslovne aktivnosti in prenose, ki potekajo preko sodobnih elektronskih medijev - interneta, mobilnih telefonov, internetnih socialnih omrežij in tudi drugih oblik napredne I K T. Danes v e-poslovanju in komercializaciji uporabljamo različne načine in nosilce, in sicer:

- internet,

- mobilni internet,

- klasično telefonijo,

- mobilno telefonijo,

- različna internetna socialna omrežja (Facebook, Twitter, LinkedIn, My Space),

- internetno telefonijo (Skype),

- ostale nosilce e-poslovanja in komercializacije. 
Danes preko interneta potekajo različne poslovne aktivnosti, ki jih izvajajo podjetja in tudi potrošniki. Najpomembnejše aktivnosti komercializacije in e-poslovanja, ki potekajo preko interneta, so:

- uporaba socialnih omrežij,

- e-pošta,

- iskanje informacij in podatkov,

- raziskave trga in neposredna komunikacija s potrošniki,

- marketinško komuniciranje - oglaševanje,

- e-bančništvo,

- prodaja storitev - rezervacija potovanj, letalskih kart,

- izvedba telekonferenc, videokonferenc in poslovnih srečanj,

- prodaja in nakupovanje.

E-poslovanje in komercializacija ima pred klasičnim načinom poslovanja določene prednosti, saj je sodobno, poteka hitro, je stroškovno zelo ugodno, je široko dosegljivo in ob upoštevanju potrebnih postopkov komercializacije ter poslovanja tudi dokaj varno. Slabost poslovanja preko interneta je možnost špekulativnega poslovanja in komercializacije zaradi ključnega razloga, ker internet nad seboj nima nobenega regulatorja in je tako možno tam prikazati tudi tisto, kar v resnici ne obstaja, to pa lahko podjetja in posameznike zavaja ter vodi tudi do špekulativnih in kriminalnih postopkov v komercializaciji in poslovanju. Zato je potrebno biti tudi pri e-poslovanju previden in upoštevati vsa veljavna pravila ter postopke za e-poslovanje.

V bodoče je pričakovati še večji razmah, še hitrejšo širitev in intenzivnost e-poslovanja ter komercializacije kot posledico razvoja tudi nekaterih novih, inovativnih načinov e-poslovanja in komercializacije, emarketinga in e-marketinškega komuniciranja.

\section{Vprašanja za utrjevanje}

1. Kaj omogoča sodobna informacijsko-komunikacijska tehnologija (I K T)?

2. Kako bi lahko opredelili e-poslovanje?

3. Katere načine in nosilce uporabljamo v sodobnem e-poslovanju in komercializaciji?

4. Katere so najpomembnejše aktivnosti e-poslovanja in komercializacije?

5. Kakšne prednosti ima e-poslovanje in komercializacija?

6. Kakšne so slabosti e-poslovanja in komercializacije?

7. Kakšen je pričakovan bodoči razvoj e-poslovanja in komercializacije? 


\section{Preverjanje novosti na trgu \\ - Kaj pomeni spremljanje tehnološkega stanja (technology watch) \\ - Zakaj so pomembne patentne baze \\ - Ali nam patentne baze omogočajo pridobiti informacijo o podjetju, ki patent komercialno izkorišča}

\subsection{Spremljanje tehnološkega stanja (technology watch)}

Spremljanje tehnološkega stanja pomeni ugotovitev stanja na raziskovalnem, tehnološkem in tržnem področju v mednarodnem merilu. Želimo ugotoviti, kaj je bilo na določenem področju tehnologije že narejeno oziroma kakšne so smernice razvoja. Poznavanje stanja je zaradi hitrega razvoja tehnologije in globalizacijskih učinkov potrebno tako pri samem razvoju novih izdelkov in storitev, izboru materialov in sestavnih delov, nabavi razvojne in proizvodne opreme, logistiki kot tudi pri spremljanju razvoja konkurence in njenih tržnih aktivnosti. Rezultati analize služijo tudi pri managerskem odločanju o novih invencijah in seveda pri strateških odločitvah vodstva (Likar 2007).

Pomembni deli spremljanja tehnološkega razvoja so navedeni v preglednici 10.1 in segajo vse od razvojnih smernic za 5-10 let vnaprej, ki jih na primer spodbuja E U, pa prek pregleda patentnih baz do konkretnih tržnih proizvodov, ki so konkurenca že danes.

Veliko možnosti nam omogoča internet, vendar je potrebno poglobljenejše iskanje. Celo profesionalne obveščevalne službe v zadnjem obdobju zberejo prek interneta velik delež informacij, ki jih potrebujejo za svoje delo - po nekaterih podatkih prek $80 \%$. S spletnih strani zberemo podatke, jih razvrstimo po pomembnosti, analiziramo ter oblikujemo zaključke, potrebne za uspešno in učinkovito usmerjanje lastnega tehnološkega razvoja. Obstajajo tudi določeni servisi, organizacije ali skupine, ki na spletu objavljajo že opravljene raziskave s specifičnih področij. Pogosto pa se moramo zateči tudi k strokovnjakom, ki so se specializirani za tovrstne raziskave (Likar, Križaj in Fatur 2006).

Načini za preverjanje so zagotovljeni prek interneta - tako lastne 
Preglednica 10.1 Spremljanje tehnološkega razvoja

\begin{tabular}{|c|c|c|}
\hline Vrsta podatkov & Viri informacij & Nivo uporabnosti \\
\hline $\begin{array}{l}\text { Razvojne smernice } \\
\text { držav, E U, U SA, Ki- } \\
\text { tajska, Japonska ipd. }\end{array}$ & $\begin{array}{l}\text { Vladni dokumenti; uradne } \\
\text { spletne strani držav, E U, npr. } \\
\text { CORDIS; nekatere vodilne } \\
\text { znanstvene revije. }\end{array}$ & Strateško odločanje podjetij. \\
\hline $\begin{array}{l}\text { R R projekti (trenu- } \\
\text { tni) - univerze, insti- } \\
\text { tuti, komercialni raz- } \\
\text { iskovalni laboratoriji }\end{array}$ & $\begin{array}{l}\text { Specializirane baze podatkov } \\
\text { (nacionalne, E U - H 2020, } \\
\text { cORDIS - Programmes ipd.); } \\
\text { objave na znanstvenih konfe- } \\
\text { rencah. }\end{array}$ & $\begin{array}{l}\text { Strateško odločanje; vir zna- } \\
\text { nja in idej za podjetja z vo- } \\
\text { dilno strategijo. }\end{array}$ \\
\hline $\begin{array}{l}\text { R R projekti (zaklju- } \\
\text { čeni) - univerze, in- } \\
\text { štituti, komercialni } \\
\text { raziskovalni labora- } \\
\text { toriji }\end{array}$ & $\begin{array}{l}\text { Specializirane baze podatkov } \\
\text { (nacionalne, E U - H 2O2O, } \\
\text { coRDIS - Projects and re- } \\
\text { sults ipd.); objave v znan- } \\
\text { stvenih in v strokovnih revi- } \\
\text { jah; poročila R R skupin in na- } \\
\text { cionalnih ter E U razpisov. }\end{array}$ & $\begin{array}{l}\text { Strateško odločanje; vir zna- } \\
\text { nja in idej, predvsem za pod- } \\
\text { jetja z vodilno strategijo. }\end{array}$ \\
\hline Patenti & $\begin{array}{l}\text { Specializirane baze podatkov } \\
\text { o podeljenih patentih (Espa- } \\
\text { cenet, U S P T O ...); patentni } \\
\text { zastopniki. }\end{array}$ & $\begin{array}{l}\text { Strateško odločanje; vir zna- } \\
\text { nja in idej, predvsem za pod- } \\
\text { jetja z vodilno strategijo; vir } \\
\text { znanja in idej tudi za sledilce. }\end{array}$ \\
\hline $\begin{array}{l}\text { Podjetja - komerci- } \\
\text { alna ponudba }\end{array}$ & $\begin{array}{l}\text { Spletne strani podjetij in } \\
\text { druga gradiva; specializirane } \\
\text { baze (rumene strani ipd.); } \\
\text { sejmi, razstave. }\end{array}$ & $\begin{array}{l}\text { Strateško odločanje; vir zna- } \\
\text { nja in idej za podjetja s sle- } \\
\text { dilno in z vodilno strategijo; } \\
\text { vir znanja in idej tudi za sle- } \\
\text { dilce. }\end{array}$ \\
\hline Analize ekspertov & $\begin{array}{l}\text { Specializirane baze podat- } \\
\text { kov; patentni/komercialni } \\
\text { brokerji za določene indu- } \\
\text { strijske panoge; izdelava štu- } \\
\text { dij po naročilu. }\end{array}$ & $\begin{array}{l}\text { Strateško odločanje; vir zna- } \\
\text { nja in idej za podjetja z vo- } \\
\text { dilno in s sledilno strategijo. }\end{array}$ \\
\hline Druge informacije & $\begin{array}{l}\text { Makroekonomska poročila, } \\
\text { finančni izkazi podjetij, bor- } \\
\text { zni podatki, novice ipd. }\end{array}$ & $\begin{array}{l}\text { Strateško odločanje; vir zna- } \\
\text { nja in idej za podjetja. }\end{array}$ \\
\hline
\end{tabular}

spletne strani podjetij kot forumi, kjer si uporabniki izmenjujejo izkušnje. Za analizo konkurence so koristne tudi analize proizvodov, ki jih opravljajo neodvisne institucije. Za področje fotoaparatov je taka stran na primer http://www.dpreview.com/. V Sloveniji pa neodvisne primerjane teste opravlja na primer Zveza potrošnikov Slovenije (https://www.zps.si/). Velja si ogledati tudi spletne strani, na katerih se specializirajo za spremljanje tehnološkega napredka. 
Popolnih informacij seveda ne boste našli nikjer, lahko pa na spletu najdete že opravljene obširnejše študije, razprave, preglede, ocene itd., ki se vsaj delno skladajo $z$ vašim področjem zanimanja. Tako so trenutno na strani http://www.itu.int/en/ITU-T/techwatch/Pages/default.asp na voljo dokumenti o tehnološkem razvoju na področjih Tactile Internet, Big data, Location-based services, Mobile money, Technologybased learning itd. Zanimiva je tudi stran http://www.dpconline.org/ advice/technology-watch-reports, ki obljublja temeljito recenzirana poročila o stanju tehnologij.

\section{Samostojno ali s pomočjo strokovnjaka?}

Pregled stanja tehnike večja podjetja opravljajo pogosto sama, mala in srednja podjetja pa lahko naročijo analizo pri institucijah, ki so za to usposobljene. Cene se glede na kakovost gibljejo od nekaj tisoč pa tudi do nekaj deset tisoč evrov. Dobra analiza je možna le ob dobro usposobljenem strokovnjaku - generalistu, ki pozna način dela, razpolaga s pogosto plačljivimi bazami podatkov ter sodeluje s strokovnjaki s konkretnih področij (univerz, fakultet, s svetovalci, $\mathrm{z}$ vrhnim vodstvom podjetja ipd.). Delo poteka v veliki meri prek interneta, saj je ob vešči uporabi to izjemen vir informacij.

Omeniti je potrebno, da nekatera podjetja del tega procesa pravzaprav izvajajo trajno. Spremljajo različne internetne ali drugačne vire, obiskujejo sejme, razstave, tudi strokovne konference. Vsaj delno poznajo konkurenco in dobavitelje tehnologije in opreme. Vendar praksa kaže, da sistematična analiza $\mathrm{z}$ novimi in poglobljenejšimi pristopi prek strokovnjakov za podjetje pomeni dodano vrednost, ki jo to s pridom uporabi v poslovnem procesu (Likar 2007).

Nekaterim od navedenih elementov tehnološkega stanja bomo posvetili še nekoliko več pozornosti.

\subsection{Preverjanje patentnih baz}

Iskalnikov po zbirkah patentov je na internetu veliko, nekaj je tudi brezplačnih. Med takimi se v praksi najbolje izkažeta iskalnik ameriškega patentnega urada U S P T O na spletni strani www.uspto.gov/patft in iskalnik evropskega patentnega urada E P O na spletni strani ep.espacenet .com. Prvi omogoča iskanje po ameriških patentnih spisih, brez česar ni resne poizvedbe, drugi pa vzajemno iskanje po evropski (E PO), mednarodni (WIPO) in svetovni (Worldwide - prek 90 držav) patentni zbirki. Iskalnik E PO je dostopen tudi prek spletne stran Urada za 


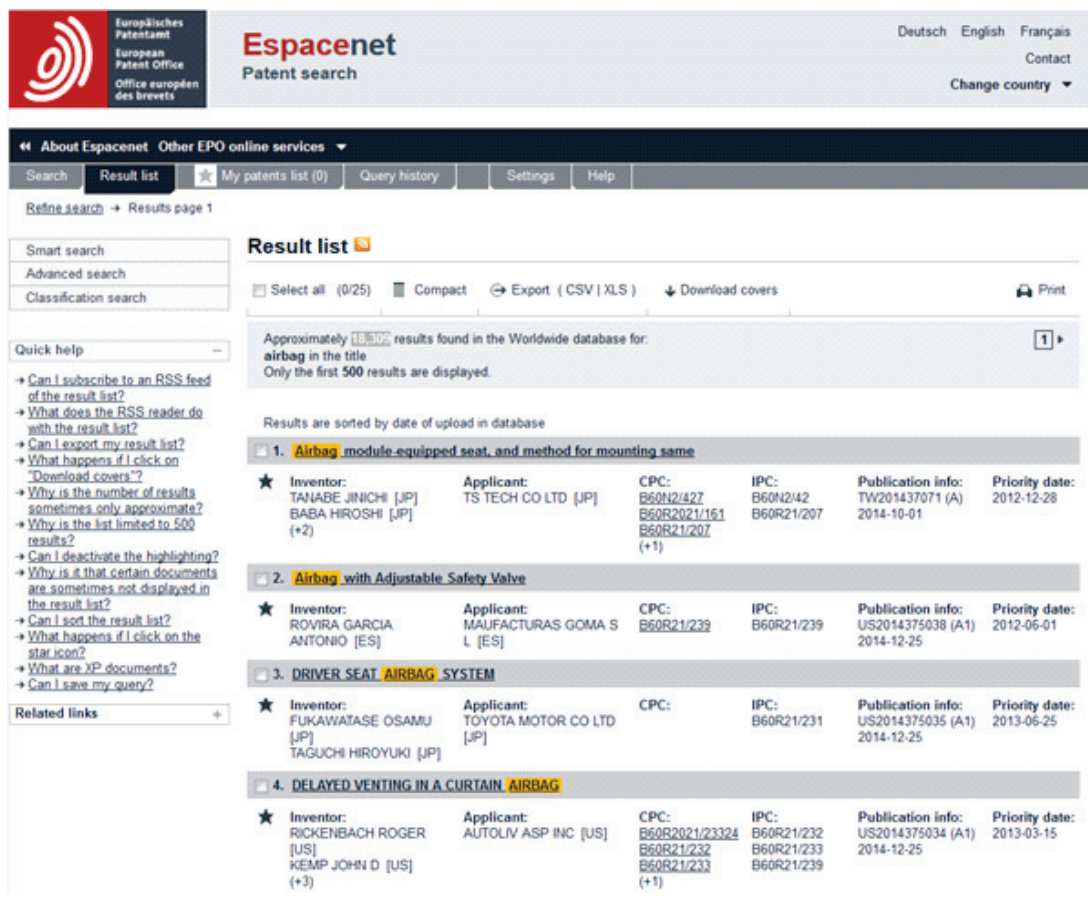

Slika 10.1 Primer iskanja po bazi patentov (po https://worldwide.espacenet.com)

intelektualno lastnino RS (http://www.uil-sipo.si/uil/dejavnosti/baze -podatkov/). Vedno uporabnejši pa je tudi iskalnik Google Patents.

\section{Iskanje po bazi}

Ob uporabi iskalnika običajno pridobimo več zadetkov, ki ustrezajo iskalnemu nizu. Izpišejo se številke patentov, datum izdaje in naslov patenta. Na sliki 10.1 je prikazan rezultat poizvedbe po patentni zbirki E P O za »airbag « - torej za zračno blazino. Ker je zadetkov kar 18.309, je smiselno iskanje dodatno omejiti. Če nas zanimajo patentni v povezavi $\mathrm{z}$ motorji, poskusimo $\mathrm{z}$ novo poizvedbo za "airbag motor«. Zadetkov je le še 6.771, za isti iskalni niz v povezavi $\mathrm{z}$ voznikom »airbag motor driver« pa še 348. Iskanje lahko dodatno omejujemo ali pa pričnemo pregledovati patente.

\section{Rezultat iskanja}

Prva selekcija so naslovi patentov, po katerih patente najprej pregledamo. S klikom na številko patenta dobimo osnovne podatke o pa- 
tentu, vključno s povzetkom, navedeno literaturo, seznamom patentov, na katere se patent nanaša, pa tudi patente, ki ta patent omenjajo. Vse to nam olajša delo pri nadaljnjem iskanju, saj z enim dobrim »zadetkom « zelo preprosto poiščemo še vse podobne. Poleg opisanega je v patentu zapisana tudi klasifikacija, v katero je patent uvrščen. S klikom na osnovno klasifikacijo, ki nastopa v patentu, dobimo vse zadetke patentov, ki vključujejo to klasifikacijo, obenem pa še spisek sorodnih klasifikacij (zelo uporabno).

Informacij o tehnološkem razvoju na spletu je torej veliko, le potrebno si je vzeti nekaj časa, jih dobro prebrskati ter »ločiti zrnje od plev«. Na voljo je celo strojni prevod, ki je kljub netočnosti dobrodošel, saj poleg slike dobimo tudi vpogled v vsebino, ki strokovnjaku lahko pove precej.

\section{Patent in komercialna ponudba na podlagi le-tega}

Če je naša rešitev glede na prikazano, še posebno pa glede na patentne zahtevke podobna patentirani rešitvi, je potrebno prijavo podrobno preučiti, saj nam to lahko prepreči patentiranje in komercializacijo naše novosti. V kolikor nismo strokovnjaki, je sodelovanje s patentnimi strokovnjaki nujno. Glede na to, da je lastnik prikazanega patenta naveden (Honda), je naslednji korak preverjanje njihove komercialne ponudbe.

V kolikor se patentirana rešitev pojavi tudi v tržnih proizvodih, gre očitno za patent, za katerega so ocenili, da je tržno zanimiv. Če pa je patent starejšega datuma in po več letih ni v komercialni ponudbi, pa obstaja verjetnost, da kljub zaščiti ni bil primeren za komercializacijo. To je za nas pomemben podatek $v$ smeri, da morda tudi naša, podobna rešitev ne prinaša tržne zanimivosti.

\subsection{Preverjanje konkurenčnih tržnih proizvodov}

Pri iskanju morebitnih konkurenčnih izdelkov moramo biti pozorni na dejavnike, ki jih navajamo spodaj.

- Obstoj tržnih proizvodov, ki so glede na tehnologijo oziroma rešitve primerljivi $z$ našo novostjo in predstavljajo neposredno konkurenco,

- Obstoj tržnih proizvodov, ki uporabljajo drugačne rešitve in tehnologije, a opravljajo isto funkcijo. Za kupca v večini primerov namreč ni pomembno, kako proizvod reši njegovo potrebo, ampak predvsem, da jo ustrezno reši. Tako se na primer za tekaške smuči upo- 
Bibliographic data: JP2011235814 (A) - 2011-11-24

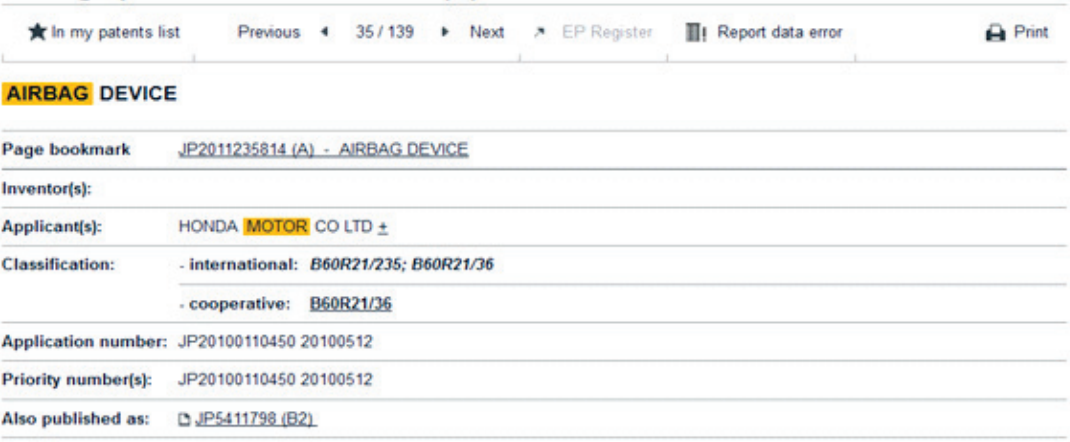

Abstract of JP2011235814 (A)

Translate this text into i

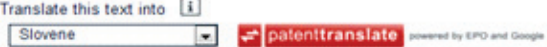

PROBLEM TO BE SOLVED: To ensure uniform shock absorbing performance over the entire length in a longitudinal direction, by reducing the rigidity of both ends of a metal airbag for protecting a pedestrian. : SOLUTION The tubular airbag 18 in which a folded metal plate closes openings of both ends $34 \mathrm{a}$ in a longitudinal direction never shrinks if it once expands, and absorbs shock of a pedestrian by elastic deformation of the metal. Thus, an inflator having a low volume is employed to reduce weight and cost, and in addition, a stable shock absorbing performance can be exhibited irfespective of deviation of timing of collision of a pedestrian. Further, both longitudinal ends $34 \mathrm{~b}$ of the airbag 18 which has the possibilty of reducing shock absorbing performance caused by high rigidity due to difficulty in inflation has a plate thickness smaller than the thickness of a longitudinal center 34 a which is easily inflated. With this configuration, the rigidity of both the longtudinal ends 34 a is reduced while maintaining the rigidity of the longitudinal longivdina ends 34 a is reducod wile maintaining the rigidy of the longitudinal center $34 \mathrm{~b}$ to make it possible to ensure uniform shock absorbing performance over
the whole length of the airbag. 18 COPYRIGHT. (C) 2012.JPOSINIPIT
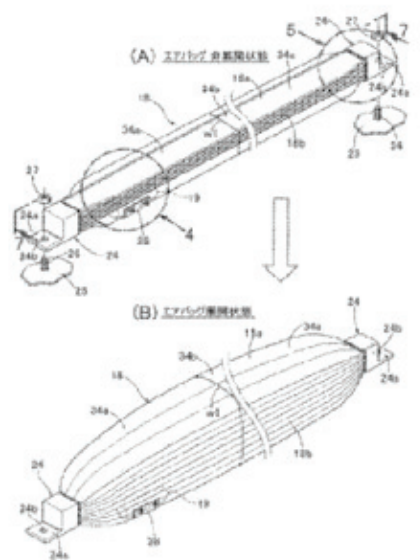

Slika 10.2 Primer patenta (po https://worldwide.espacenet.com)

rabljajo maže za preprečevanja zdrsa pri odrivu. Konkurenca mažam enega proizvajalca pa niso le ostali proizvajalci maž, pač pa tudi drugi načini za preprečevanje zdrsa. Ti so na primer luskine na spodnji strani smuči, tako imenovani moher oziroma trakovi iz kože idr.

- Morebiten patent pa ni edina ovira pri komercializaciji. Če enaka rešitev kje na svetu že obstaja in je bila javnosti dostopna, pa čeprav zanjo ni bila vložena/pridobljena patentna prijava, nam to onemogoča prijavo identične rešitve/patenta. To pomeni, da lahko rešitev komercialno izkorišča vsak. 


\section{Vprašanja za utrievanje}

1. Kaj pomeni spremljanje tehnološkega stanja (technology watch)?

2. Katere patentne baze poznate in kaj nam nudijo?

3. Kako poteka iskanje po patentni bazi? 



\section{Oblike komercializacije novosti \\ - Katere so oblike za komercializacijo novosti \\ " Kaj je značilno za licenciranje \\ " Kateri so načini za prodajo licence}

Doslej smo dovolj povedali o tem, da je inovacija »blago« posebne vrste. Zmotna je miselnost, da se inovacija prodaja kot vse ostalo blago, ki ga kupec že bolj ali manj pozna in je njegov tok prodaje že utečen. Kupec - kdorkoli že to je - je do novosti pogosto previden in čaka, da bo videl, kako se bo na trgu obnesla, kakšne bodo strokovne ocene in kam se bo obrnilo javno mnenje. To je glavni razlog za to, da je prodaja inovacije težja in zahteva drugačen tržni pristop kot prodaja znanega artikla. Žal nimamo časa, da bi se ukvarjali s teorijo disfuzije novosti (Rogers 2003; Mulej in Ženko 2004).

To je dovolj velik razlog tako za inventorja - posameznika kot za podjetje, da se nauči kvalificirane prodaje - da osvoji vsaj temeljne elemente inovacijskega managementa. $V$ tako oteženem položaju je treba za nov proizvod začeti iskati vse možne prodajne poti. In teh ni tako malo, kot bi si mislili (Likar, Križaj in Fatur 2006):

- podjetniška dejavnost,

- lastno podjetje,

- skupna naložba,

- skupno podjetje,

- spin-off,

- prodaja invencije oziroma intelektualne lastnine,

- licenciranje,

- odprodaja intelektualne lastnine.

\subsection{Podjetniška dejavnost}

\section{Lastno podjetje}

Ustanovitev in vodenje lastnega podjetja je zanimiv izziv, ki pa zahteva celega človeka. To je praviloma naporna pot, na katero moramo biti pri- 
pravljeni. Za marsikoga je to življenjski moto, saj mu omogoča dinamično življenje, ki si ga kroji po lastnih zamislih. Za marsikoga pa je ob izgubi službe to nuja. V Sloveniji »biti podjetnik« še vedno večinoma ni vrednota in želja večine.

Ustanovitev lastnega podjetja je smiselna v primerih, ko imamo za to potrebne vire (ljudi, sredstva, opremo ... ali pa vsaj idejo in veliko volje). Pomemben je tudi potencialni trg. Skušati konkurirati na področju množične proizvodnje je večinoma nesmisel. Uspešna majhna in mlada podjetja praviloma iščejo tržne niše in gradijo na specifičnih znanjih, virih in idejah, ki prinašajo tržne prednosti.

\section{Skupna naložba}

Pri skupni naložbi gre za obliko sodelovanja z nekom (posameznikom ali podjetjem), ki ima določena znanja, izkušnje, tehnologijo, trge, finančna sredstva ipd. Namen je torej pridobitev komplementarnih virov. Skupna naložba pomeni po eni strani delitev del in odgovornosti pa tudi zaslužka.

Prednosti. Pogosto se ustanovi tudi zato, ker se določene investicije tako lažje financira, zmanjša se tveganje pa tudi hitreje pridemo s proizvodom na trg, kar je danes še kako pomembno. Tudi če z idejo začnemo kot posameznik, je včasih smiselno sodelavce povabiti v skupno naložbo, saj tako ni potrebno financirati na primer dragega razvoja, ki ga partner opravi kot vložek v podjetje.

Slabosti. Te so potreba po trajnem dogovarjanju in neredki nesporazumi. Vsekakor pa je smiselno jasno definirati vložke vsakega od partnerjev - finančne, vloženo delo, opremo, know-how oziroma intelektualno lastnino.

\section{Skupno podjetje}

Pogosto je skupna naložba prehodna oblika sodelovanja. Ko posel steče, je pogosto smiselno ustanoviti novo podjetje, kjer so lastniški deleži in ostale oblike pravno-finančnih zadev jasno urejene.

\section{Spin-off}

Spin-off oziroma hčerinska podjetja so posebna oblika "navadnega« podjetja. Nastanejo praviloma na podlagi znanja in intelektualne lastnine (IL) raziskovalcev iz (najpogosteje) javnih inštitutov oziroma univerz (J RO - javna raziskovalna organizacija). Ključni cilj je komercializacija in ustvarjanje dobička s izkoriščanjem know-howa oziroma 


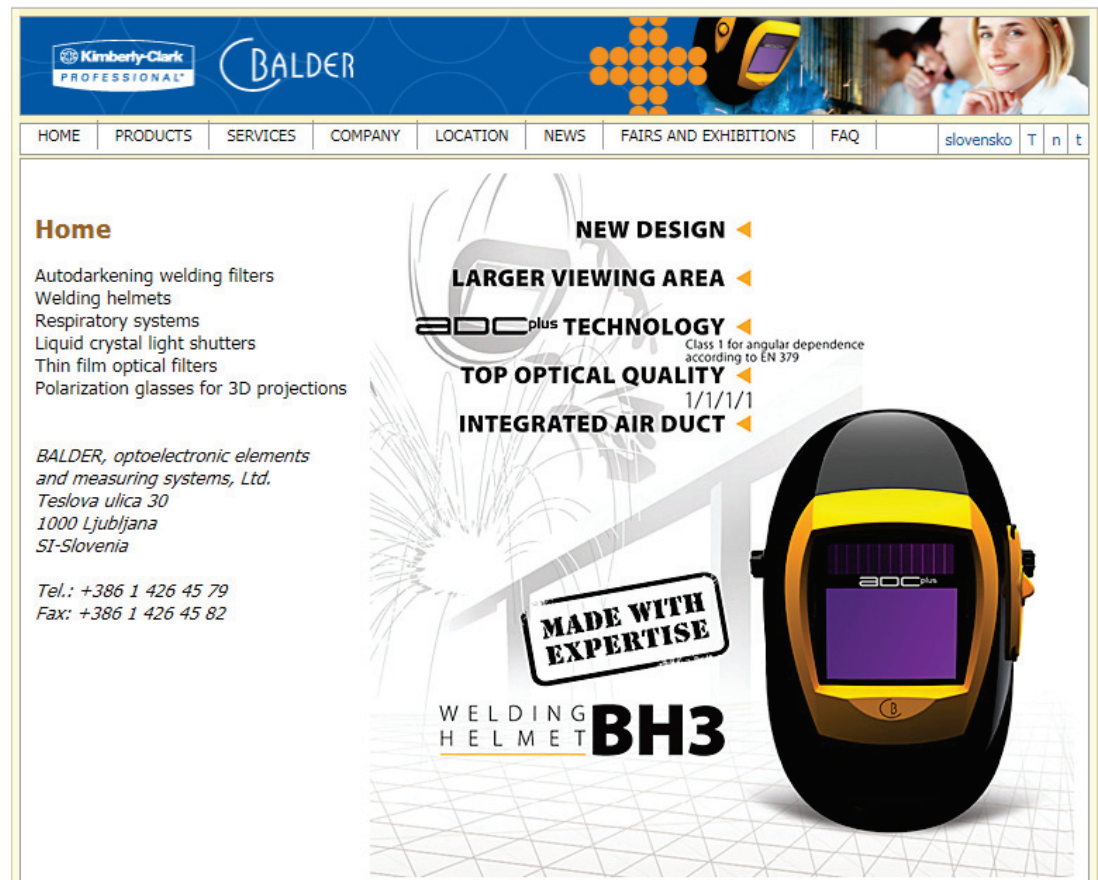

Slika 11.1 Spletna stran domačega spin-off podjetja Balder, ki je specializirano za razvoj in proizvodnjo optoelektronskih elementov na osnovi tehnologije tekočih kristalov

pravic intelektualne lastnine, katerih imetnik je bila J RO. Intelektualna lastnina predstavlja tudi vložek JRO kot del celotnega vložka v novo podjetje. $S$ tem postane JRO solastnik le-tega, ostali lastniki pa so pogosto raziskovalci iz JRO. Lastniški delež JRO ne presega 49\%, saj bi ostalim ustanoviteljem otežil odločanje o tekočem poslovanju družbe.

\subsection{Prodaja invencije oziroma intelektualne lastnine}

\section{Licenciranje}

Gre za sporazum z enim ali z več podjetji, ki jim z licenčno pogodbo dovolite izkoriščanje vaše intelektualne lastnine. Elemente pogodbe določite glede na sporazum, ki ste ga predhodno dogovorili. Navadno gre za zahtevna pogajanja, s katerimi definirate vse medsebojne obveznosti. V dogovore in pripravo pogodbe je smiselno vključiti pravne strokovnjake oziroma patentne zastopnike (ki so pogosto tudi pravni strokovnjaki).

Lastnosti:

- Kupec pridobi ekskluzivno pravico izkoriščanja. 
- Eden pomembnih elementov je sorazmernostno načelo, ki določa višino licenčnine kot delež ustvarjenih prihodkov kupca licence. Poenostavljeno povedano, izumitelj dobi določen odstotek od prihodkov novega lastnika licence.

- Licenco se lahko proda samo za določene trge, časovno obdobje ali pa za uporabo v obliki vnaprej določenih končnih izdelkov.

Za mnoge izumitelje oziroma raziskovalce/profesorje je to najprimernejša oblika izkoriščanja izuma. Še posebno v sledečih primerih:

- ne želijo stopiti v podjetniške vode;

- ne izpolnjujejo pogojev za ustanovitev podjetja (sredstva viri ipd. - glej poglavje Podjetje);

- hitro lahko pridejo do sredstev;

- ne želijo prevzeti tveganja pri komercializaciji in pri varovanju IL pred tretjimi osebami (na primer posnemovalci - kraja ali posnemanje).

Pogoj za licenciranje ali odprodajo:

- velika komercialna zanimivost - ta mora biti večja kot v primeru, da se odločimo za komercializacijo prek lastnega podjetja;

- kakovostna zaščita - ta je odvisna od kakovosti same prijave, predhodnih prijav in tudi narave novosti.

Nekatere rešitve se lahko razmeroma dobro zaščiti, vse pa zaradi narave izuma ne nudijo možnosti za enako dobro zaščito.

Določene vrste izumov sami sploh ne moremo izkoriščati in je licenciranje skorajda edina možna oblika komercialnega izkoriščanja, kot opredeljujejo spodnji primeri.

- Sestavni deli izdelkov, naprav oziroma sistemov, kjer je naš izum le del celote (ki je varovana že z drugimi patenti). Tak primer je na primer regulacija temperature $v$ loncu s pomočjo merjenja temperature $\mathrm{v}$ pokrovki, ki deluje le $\mathrm{v}$ povezavi s štedilnikom. Licenciranje je smiselno za proizvajalca štedilnikov, ki bo ustrezno tehnologijo vgradil $v$ štedilnik in izdeloval tudi napravo, ki se jo pritrdi na pokrovko. Podoben primer je odpirač na pločevinki, ki je funkcionalen $\mathrm{v}$ povezavi s pločevinko.

- Izdelki, ki so izredno dragi oziroma imajo visoke zagonske stroške in zahtevajo množično proizvodnjo (na primer izdelava »custom design elektronike«). 


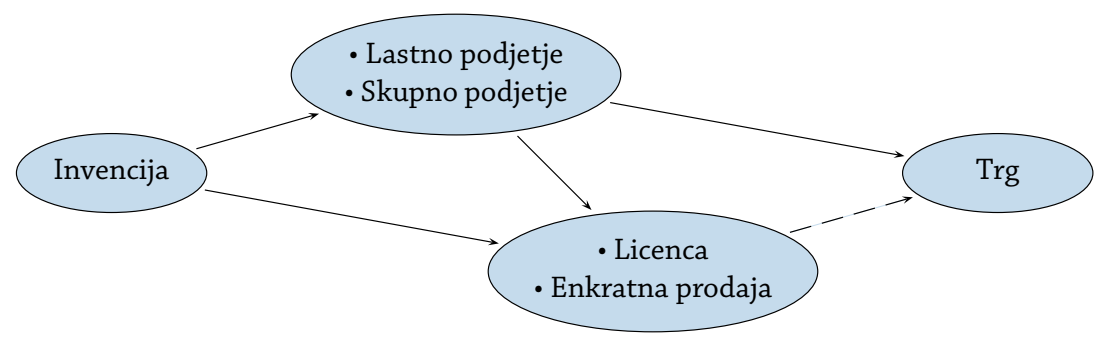

Slika 11.2 Oblike komercializacije novosti

- Večino trga nadzira eno podjetje (na primer Windows nadzira Microsoft).

Pri visokotehnoloških izdelkih se včasih ustanovi podjetje le zato, da poskrbi za licenciranje I L in nadzoruje dogovor iz licenčne pogodbe (glej http://www.uil-sipo.si/uil/urad/prirocnik-za-izumitelje).

\section{Odprodaja intelektualne lastnine}

Posebna oblika licenciranja je enkratna prodaja. Obstajajo prednosti in slabosti.

Prednosti:

- Za izumitelja je majhno tveganje v primeru neuspeha na trgu.

- Finančni priliv je za izumitelja hiter.

- Ni večje odgovornosti (v primeru skritih slabosti izuma, konfliktov zaradi novih dejstev o lastništvu izuma - lahko se na primer kasneje pojavi nekdo, ki je že pred vami izumil »vaš izum«).

- Tveganje neplačevanja za izumitelja je manjše, saj včasih težko kontroliramo obseg izkoriščanja s strani kupca.

- Kupec licence se ogne dolgoletnim obveznostim in lahko fleksibilneje uporablja IL.

Slabosti:

- Za izumitelja predstavlja praviloma manjši znesek.

- V primeru nadpovprečnega tržnega uspeha ni dodatnih nadpovprečnih prihodkov za izumitelja.

- Za kupca licence prinaša določeno tveganje (glej »ni večje odgovornosti« pri prednostih). 


\subsection{Načini prodaje licence \\ Poslovne predstavitve}

Te so namenjene predvsem zainteresirani publiki in inventorju nudijo možnost, da podrobneje osebno obrazloži svojo zamisel. Taka predstavitev običajno ni organizirana na javnem prostoru, ampak je delno zaprtega tipa, pri njej pa imajo možnost strokovnjaki postavljati tudi neprijetna vprašanja.

Oblike osebne predstavitve predstavljajo tudi gospodarske delegacije, ki potekajo večinoma $\mathrm{v}$ državnem okviru ali okviru različnih poslovnih združenj oziroma gospodarskih zbornic (Likar idr. 200o).

\section{Osebna ponudba}

To je ena osnovnih variant, ki ne gradi samo na znancih, ki jim med večerjo ponudimo našo novost. Temelji na predhodnem iskanju najzanimivejših podjetij in tudi na večji osebni prepričljivosti, kar pri preprodajalcih ni ravno pogosta lastnost. Pri lastnem trženju - še posebno, če so ciljna publika podjetja - imamo na voljo mnogo virov informacij, ki nam pomagajo čim natančneje določiti ciljno skupino potencialnih kupcev. Gre predvsem za:

- poslovne imenike, na primer PIRS, Bizi.si ipd.;

- mednarodne podatkovne baze, na primer rumene strani (yellow pages); selekcionirane informacije lahko dobimo na primer prek Gospodarske zbornice Slovenije (GzS), baze Kompass in drugih ponudnikov poslovnih baz.

\section{Specializirani sejmi}

Sejmi predstavljajo možnost predstavitve bodisi širokim množicam ali pa ozko usmerjeni ciljni skupini poslovnežev. Največkrat so prirejeni enkrat letno, večinoma ob določenem terminu.

Splošni razstavljajo proizvode več različnih gospodarskih panog, specializirani proizvode posameznih industrijskih področij, za predstavitev novosti pa so zanimivi tudi sejmi invencij in inovacij. Po svetu se vsako leto zvrsti kar nekaj mednarodnih inovacijskih sejmov od Pekinga na Daljnem vzhodu do Ženeve in Bruslja v Evropi ter Pittsburgha v ZDA oziroma Seula v Južni Koreji. Obširen seznam vsakoletnih prireditev te vrste je mogoče dobiti v eni od publikacij Gospodarskega vestnika, ki izide enkrat letno. 


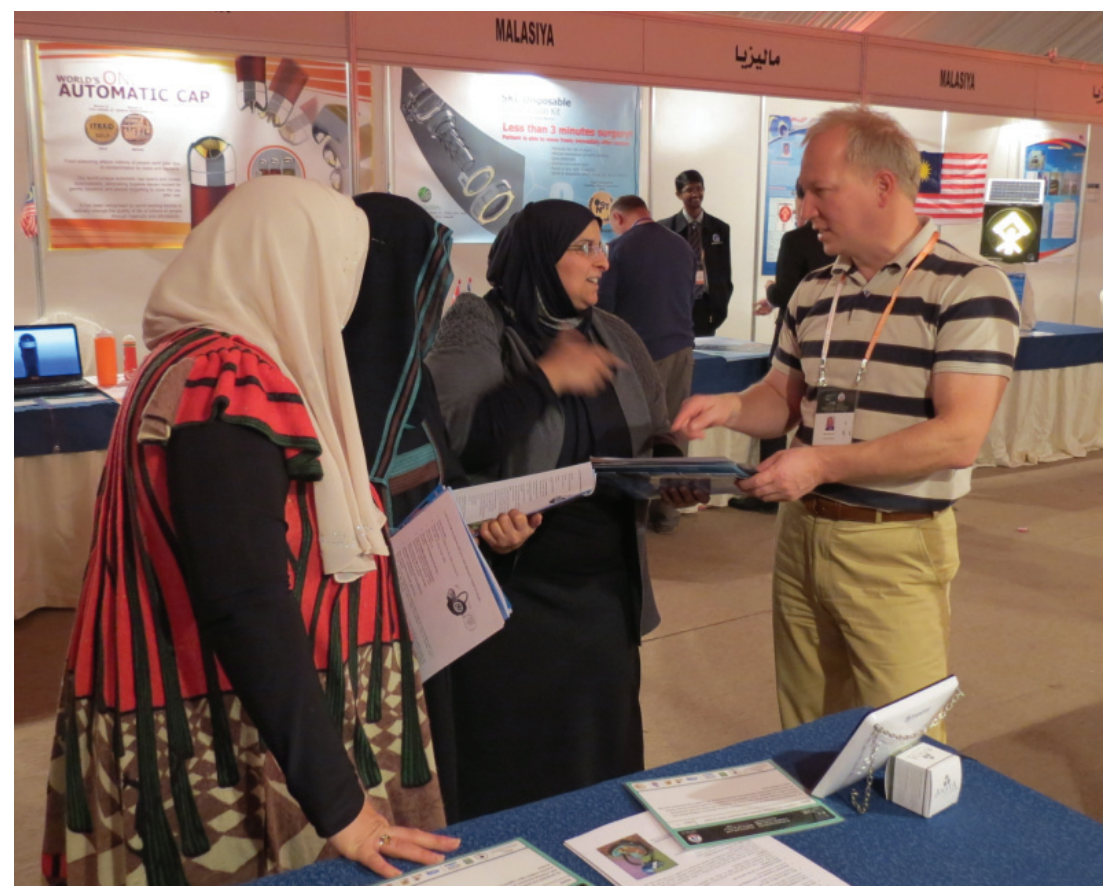

Slika 11.3 Sejem inovacij v Kuvajtu

Koristno podporo pri udeležbi na sejmih nudi inovatorski center AS I - Aktivni slovenski inovatorji. Brezplačno razstavljanje nekaterih tehnoloških dosežkov je možno tudi prek nekaterih slovenskih programov oziroma organizacij, ki se iz leta v leto spreminjajo (Likar, Križaj in Fatur 2006).

\section{Prodaja s pomočjo inovacijskih brokerjev}

To so pooblaščeni zastopniki - posredniki med zainteresiranim kupcem in prodajalcem. Poznati morajo tržišče in zakonodajo, kar jim omogoča, da prodajo invencije. Od dogovora med brokerjem ter lastnikom ideje je odvisno, kolikšen delež dobička si bo posrednik obdržal, če bo uspešen. Zastopnik odgovarja za škodo, ki jo je storil z nemarnim izvrševanjem posla ali s prekoračitvijo pooblastil. Inovacijski brokerji so pogosto povezani v mednarodne združbe - posredniško-brokerske mreže, ki delujejo v več državah. Kakovosten broker je lahko dobra pot k sklenitvi posla. Potrebno pa je upoštevati, da se s slabimi in povprečnimi izumi ne ukvarjajo. 
Pri nekaterih »brokerjih«, še posebno pa pri posrednikih (inovacijski posredniki, podjetja za promocijo in trženje izumov ipd.) velja opozoriti na nekaj nevarnosti.

- Pogoj za sodelovanje je plačilo »članarine« v znesku več sto E U R.

- Na začetku posla želijo izdelati analizo, na podlagi katere se bodo odločali o sodelovanju z izumiteljem. Cena je od nekaj sto pa tudi čez tisoč E U R. Včasih gre za korektno narejene študije, včasih pa je izdelava študije in prejetje plačila glavni cilj "sodelovanja«.

- Obetavni analizi pogosto sledi ponudba za izdelavo profesionalnega prototipa in embalaže, ki bo olajšala prodajo. Ali pa je celo pogoj za sodelovanje. Tudi to so stroški (od nekaj tisoč E U R naprej), ki bremenijo izumitelja. Tudi za to velja enako opozorilo kot v prejšnji alineji. V zDA so znani primeri, ko so izumitelji prodali hišo, da so lahko financirali goljufive posrednike (delujejo tudi v Sloveniji).

- Njihovo sodelovanje se kljub velikim obljubam poleg plačljivih prototipov pogosto omeji na posredovanje informacij o potencialno zanimivih podjetjih in druge komaj uporabne informacije, ki jih z lahkoto najdemo prek spleta sami.

Še enkrat - ni vsak posrednik goljuf in ni vsak goljuf tudi goljuf po pravni interpretaciji. Kljub temu, da je v Z D A nekaj splošno znanih goljufov, pa jim celo učinkovito sodstvo niti nadzorne institucije ne pridejo do živega.

\section{Mediji}

V fazi predstavitve in ponudbe je sodelovanje z mediji pomembna, a pogosto slabo izkoriščena možnost. To velja tako za »klasične« kot tudi za elektronske medije.

Ciljne medije navadno izbiramo glede na ciljno populacijo, ki ji želimo novost predstaviti. Lahko gre za medije, namenjene širokim množicam (na primer pri prodaji končnega, množično uporabnega proizvoda), ali pa medije, namenjene ozkemu krogu podjetnikov (na primer za predstavitev ekološko usmerjene novosti, namenjene večjim toplotnim postajam).

Predstavitve v medijih so razmeroma draga varianta, a v fazi, ko predstavljamo izumiteljske in razvojne dosežke, lahko pričakujemo tudi kakšno brezplačno objavo. 


\section{Doma ali v tujini?}

Marsikaterim avtorjem novosti ne predstavlja zadoščenja samo uspeh in uradna prijava nečesa novega. Gre za še nekaj več. Gre za to, da kljub morebitnim težavam, ki jih pričakujejo od svoje okolice, in podcenjenosti njihove stvaritve vztrajajo pri tem, da bi jo ponudili in prodali v prvi vrsti doma, v svoji domovini. Tako domoljubi šele po dolgotrajnih neuspešnih poskusih dokončno obupajo in ponudijo svojo inovacijo tujim kupcem.

Kdor stori ta korak, mora pomisliti na to, da tujina sicer predstavlja veliko tržišče in je ob ugodni prodaji iztržek neprimerno večji kot doma. Vendar, če inovacija ni dobro zaščitena in ima še druge pomanjkljivosti, je lahko tudi izguba večja. Razen tega so tožbe, povezane z nepoznavanjem pravnega reda, slabše poznavanje tujega jezika in drage advokatske ter druge nujne storitve zagotovo omejevalni faktorji.

Nekateri inventorji, ki imajo poleg dobrih idej še druge ustrezne kvalifikacije, se s svojimi načrti odpravijo v tujino, kjer včasih nalete na podobne oblike nezaupanja kot doma, vendar v družbah, nekoliko bolj odprtih od domače, pogosteje uspejo.

Eden znanih primerov nespoštovanja domačega znanja se je zgodil pred nekaj desetletji, ko je zaposleni nekega podjetja iznašel sistem za enoročno odpiranje tople ali mrzle vode. Dotlej so izdelovali mešalne baterije za vodo tako, da sta bila na pipi vgrajena dva ventila in je bilo treba temperaturo vode uravnavati $z$ vrtenjem obeh ventilov. Ko je patent predložil svojemu takratnemu delavskemu svetu in zahteval plačilo, so mu zahtevo zavrnili, češ da je izumljanje njegova službena dolžnost (to je bilo tedaj in je danes žal v skladu z zakonom v Sloveniji in drugod mogoče, ne pa nujno). Zaposleni si je dosti upal, ko je svojo invencijo ponudil konkurentu nekaj deset kilometrov stran čez avstrijsko mejo. Ta jo je sprejel $z$ obema rokama, začel s serijsko proizvodnjo in z novim proizvodom osvojil tržišče. Ironija je hotela, da je isti delavski svet, ki je ponudbo svojega človeka odklonil, čez nekaj časa kupil mešalno baterijo kot tujo licenco in močno preplačal ceno, kakršno je od njih sprva zahteval inventor (Likar idr. 2000).

\section{Vprašanja za utrjevanje}

1. Naštejte oblike za komercializacijo novosti. Kaj je spin-off? V čem se razlikuje od običajnega lastnega podjetja?

2. Kaj je značilno za licenciranje?

3. Kateri so načini za prodajo licence? 

12 Podporno okolje glede

\section{financiranja in komercializacije}

- Katere institucije in kakšno podporo nudijo pri komercializaciji novosti

" Katere so najpogostejše oblike financiranja novosti

- Kdo so poslovni angeli in kako delujejo

" Kaj je »crowdfunding« in zakaj je na primer zanimiv Kickstarter

\subsection{Financiranje}

Zlasti na začetku, ko še nimamo uspešno zaključenih projektov, je financiranje ključno, tako glede prototipa kot glede izdelave končnega tržnega proizvoda. Čeprav namen tega priročnika ni podrobnejša predstavitev načinov financiranja, pa navajamo nekaj osnovnih možnosti.

\section{Podpora iz EU}

Države članice naj bi do leta 2020 za raziskave in razvoj namenile $3 \%$ svojega BDP (od tega 1\% javnih sredstev in $2 \%$ naložb zasebnega sektorja), kar bi v E U ustvarilo 3,7 milijona novih delovnih mest in povečalo letni B DP za skoraj 800 milijard evrov. Evropska komisija je januarja 2014 objavila najnovejši 7-letni raziskovalni program Obzorje 2020, ki do leta 2020 razpolaga s skoraj 80 milijardami evrov, ta znesek pa bodo dopolnila še sredstva iz zasebnega in javnega sektorja. V tem najnovejšem programu so združena vsa sredstva za raziskave in inovacije.

Program Obzorje 2020 bo sredstva namenil:

- utrditvi položaja EU v znanosti: 24,4 milijard evrov, vključno s 13 milijardami evrov za Evropski raziskovalni svet,

- industrijskim inovacijam: 17 milijard evrov, zajeto je tudi vlaganje $\mathrm{v}$ ključne tehnologije ter večjo dostopnost kapitala in podporo za mala podjetja,

- najpomembnejšim družbenim izzivom, kot so podnebne spremembe, trajnostni prevoz, obnovljivi viri energije, varnost hrane in prehranska varnost, staranje prebivalstva: 24,4 milijard evrov. 
Tako bo omogočil (glej http://europa.eu/pol/rd/index_sl.htm):

- da bodo tehnološke inovacije postale uporabni izdelki z dejanskim tržnim potencialom - prek partnerstev $z$ industrijo in javnim sektorjem,

- da se bo povečalo mednarodno sodelovanje $\mathrm{v}$ raziskavah in inovacijah - prek udeležbe držav in organizacij zunaj EU,

- da se bo popolnoma uveljavil evropski raziskovalni prostor.

Zanimivi so tudi nekateri drugi programi, na primer Erasmus plus (http://ec.europa.eu/programmes/erasmus-plus/index_en.htm), pa še več drugih, ki so, včasih posredno, primerni za financiranje inovacijskih in podjetniških projektov.

V okviru predstavljenih sklopov je vrsta konkretnih razpisov, ki bodo še potekali v naslednjih letih. Gre praviloma za večje zneske, od nekaj deset tisoč do več sto tisoč E U R, včasih tudi prek milijona E U R, ki so na voljo predvsem za razvoj in inovacije. Je pa priprava in vodenje projekta zahtevno in časovno potratno. Prav tako velik del razpisov zahteva partnerstvo več organizacij, praviloma iz več držav.

\section{Nacionalna podpora}

Občasno so na voljo tudi domači razpisi, ki podpirajo inovacijsko in razvojno dejavnost. Žal pa ta vir financiranja (z izjemo raziskovalne dejavnosti) ni posebno stabilen in se spreminja od vlade do vlade, iz leta $\mathrm{v}$ leto. Kljub temu pa je razpisom smiselno slediti in izkoristiti priložnost.

Ena od oblik podpore v zadnjih letih je nacionalni sistem inovacij. S P I R I T Slovenija sofinancira aktivnosti organizacij podpornega okolja, ki imajo ključno nalogo spodbujati in krepiti inovacije za trg. S tem prispevajo k učinkovitosti celotnega podpornega okolja za inovativnost, ki nudi pomoč pri uvajanju novih izdelkov, postopkov in storitev oziroma tehnoloških in netehnoloških inovacij v zasebnem sektorju (glej http://www.podjetniski-portal.si).

Podporno okolje IN O nudi svetovanja in strokovno pomoč pri:

- ustanavljanju novih inovativnih start-up podjetij,

- razvoju novih izdelkov, storitev ali postopkov,

- zaščiti intelektualne lastnine, zamisli, idej, novosti,

- uvedbi inovacij na področju oblikovanja, trženja, marketinga, prodaje, organizacije in vodenja procesov, tako imenovanih netehnoloških inovacij, 
- vključevanju v evropske iniciative.

Gre za koristne oblike podpore, saj usposobljeni strokovnjaki nudijo podporo inovativnim posameznikom in podjetjem.

\section{Množično financiranje (crowdfunding)}

Zanimive možnosti odpirajo tako imenovane platforme množičnega financiranja inovacijsko podjetniških projektov $v$ najzgodnejših fazah razvoja, ki potekajo ob podpori velikega števila ljudi. Inovator(ji) pripravi(jo) kratek prikaz, navadno $\mathrm{v}$ obliki videa, ki je dostopen prek spleta oziroma ene od omenjenih platform. $S$ tem skuša(jo) prepričati posameznike iz celega sveta, da jih podprejo z manjšimi zneski, praviloma od nekaj E U R navzgor. V zameno jim inovatorji lahko tudi kaj ponudijo - na primer izdelek, promocijo, darilce ... Vse je odvisno od avtorjev novosti in njihove iznajdljivosti. Gre za zanimiv izziv, ki pa zahteva temeljito predpripravo in odlično izvedbo. Tako je potrebno uporabiti tudi druge promocijske poti, na primer družbena omrežja, medije ipd.

Kljub majhnim posameznim zneskom gre $\mathrm{v}$ celoti za nezanemarljive zneske, saj je celoten obseg »industrije « množičnega financiranja v letu 2013 obsegal prek 5 milijard ameriških dolarjev. Med platformami pa obstajajo precejšnje razlike. Tako Kickstarter deluje na principu »vse ali nič«. Na začetku si avtorji zadajo za cilj, da bodo pridobili na primer 70.00o U SD kapitala. Če ta cilj dosežejo, denar dobijo. Če pa so zbrali le dolar manj, pa ne dobijo nič. Nekatere druge platforme pa delujejo po principu, da dobiš sorazmeren del zbranega zneska (odšteje se na primer provizija).

V Sloveniji je ena najbolj znanih platform Kickstarter, obstaja pa jih še cela vrsta (Indiegogo, Pinterests, Trevolta ...). Kar nekaj odličnih slovenskih idej je bilo na Kickstarterju že uspešnih. Eden najuspešnejših na Kickstarterju nasploh je projekt razvoja pametnega kolesa Flykly, za katerim stoji ekipa slovenskih podjetnikov. Kot prikazuje slika 12.1, so si za cilj zastavili 100.000 U S D, dosegli pa prek 700.000 U SD.

\section{Poslovni angeli}

Gre za premožnejše posameznike, ki so pripravljeni nekaj svojega kapitala investirati $\mathrm{v}$ dobre podjetniške projekte, hkrati pa so z nekaterimi poslovnimi znanji in izkušnjami pripravljeni malemu ter pogosto mlademu podjetju še dodatno pomagati pri vsakodnevnih odločitvah. Interes poslovnih angelov je povsem tržen - pričakujejo, da bodo svoj vlo- 

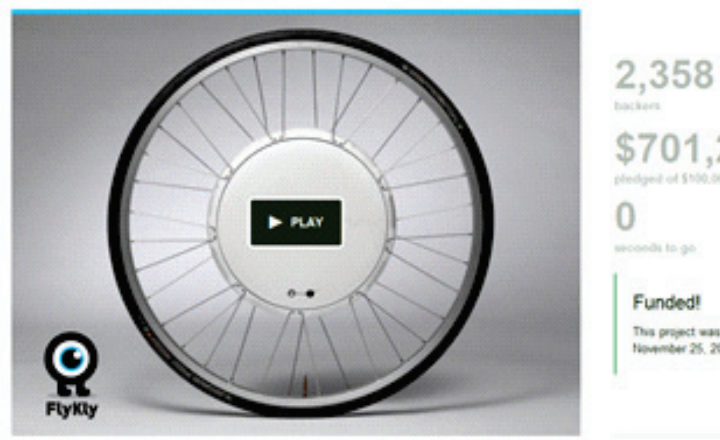

Lightweight and highly efficient all-in-one design pedal assist that fits on practically any bicycle.

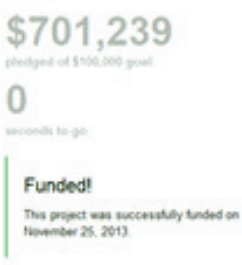

Mere Nak, ire

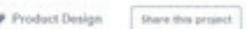

Fimon,

O Fret owiend I 11 thacked 0 nowycoen

Slika 12.1 Razvoj pametnega kolesa Flykly (po https://www.kickstarter.com)

ženi kapital kakovostno oplemenitili (kot partnerji v podjetju oziroma projektu, v katerega vlagajo), seveda pa so za to pripravljeni prevzeti tudi primerno tveganje (Likar, Križaj in Fatur 2006).

V Sloveniji so združeni v društvu Poslovni angeli Slovenije. Gre za prvi zasebni in največji formalni klub poslovnih angelov pri nas. Predstavljajo stičišče med ambicioznimi podjetniki, ki so v začetnih fazah rasti podjetja, in najuspešnejšimi slovenskimi poslovneži. Investirajo izključno $\mathrm{v}$ podjetja $\mathrm{z}$ inovativno idejo in mednarodno usmerjenostjo, saj je za hitro rast ključen velik trg. Še bolj kot dobra ideja pa je za njih pomemben ambiciozen in kompetenten podjetniški tim, ki je pripravljen trdo delati za realizacijo svoje vizije. Člani kluba so uspešni slovenski poslovneži $z$ visoko mero integritete, bogatimi podjetniškimi izkušnjami, s poslovnim in panožnim znanjem, z izjemnim socialnim kapitalom ("smart money«) ter s pripravljenostjo pomagati pri nastajanju in razvijanju novih, hitro rastočih podjetij. $\mathrm{V}$ posamezno podjetje kot poslovni angeli investirajo do $500.000 \mathrm{EU}$, in sicer $\mathrm{v}$ fazi, ko ima podjetje prototip oziroma prve stranke in izdelan poslovni načrt, ki jasno kaže njegov potencial. Z manjšinskim lastniškim deležem v podjetju želijo podjetniku čim aktivneje pomagati pri gradnji podjetja. Prepričani so, da le skupaj lahko gradijo nove mednarodne podjetniške zgodbe o 
uspehu, saj ne tekmujemo zgolj znotraj države, ampak celotnega sveta (glej http://www.poslovniangeli.si).

\section{Lastno financiranje}

Čeprav gre za finančno omejena sredstva, pa je ena osnovnih oblik lastno financiranje. Je hitra in fleksibilna oblika financiranja, ki poteka na sledeča načina:

- uporabimo lastna sredstva oziroma skušamo pridobiti podporo družinskega kroga; čeprav večinoma tako lahko računamo na omejena sredstva, so ta dosegljiva hitro in običajno brez hujših obveznosti, a tudi $\mathrm{v}$ tem primeru moramo domače prepričati, da je vlaganje smiselno in ima projekt realne možnosti za uspeh;

- »cash cow projekti« - z vzporednimi projekti skušamo zaslužiti čim več denarja, tako imenovana zagonska sredstva, da jih lahko vložimo v inovacijske projekte; iščemo predvsem take, kjer lahko v čim krajšem času zaslužimo čim več; domiselnost, samoiniciativnost in poslovno obnašanje praviloma prinašajo boljše rezultate.

\subsection{Podpora pri razvoju in komercializaciji}

\section{Tehnološki parki in inkubatorji}

Tehnološki parki in inkubatorji so institucije, ki novim podjetjem z inovativnimi programi nudijo pogoje za podjetniško rast in izvajanje razvojnoraziskovalne dejavnosti. Oba, tehnološki park in inkubator, sta pravni osebi, ki ponujata infrastrukturno in storitveno podporo začetnikom, pri čemer se tehnološki parki praviloma usmerjajo $\mathrm{v}$ realizacijo projektov, zasnovanih na visokih tehnologijah ali izdelkih in storitvah $\mathrm{z}$ visoko vsebnostjo znanja.

Poleg materialnih pogojev (prostori, informacijska oprema) tehnološki parki in inkubatorji tudi svetujejo podjetjem $\mathrm{v}$ začetni fazi rasti in razvoja ter opravljajo druge skupne funkcije, ki so potrebne za rast in promocijo podjetij - inkubirancev (administracija, informacije, marketing, kapital, kredibilnost ...). Podjetjem na začetku priskrbijo osnovno podporo, po določenem času pa se morajo ta postaviti na svoje noge.

Tehnološki parki so, sodeč po izkušnjah v svetu, ena od najučinkovitejših oblik promocije in spodbujanja razvoja podjetništva, zasnovanega na naprednih tehnologijah. Običajno so del strategije gospodarskega in družbenega razvoja mesta, regije ali države. Temeljna cilja tehnoloških parkov sta izkoriščanje infrastrukture in ustvarjanje pogojev 
za prenos visoko zahtevnih tehnoloških programov v industrijo. Prav tako je pomembno ustvarjanje novih delovnih mest, kjer se s koncentracijo raziskovalno-razvojnih potencialov dosegajo sinergijski učinki znanja in idej. Pomembno pa je vedeti, da neposredne finančne podpore ne nudijo, pač pa pomagajo $\mathrm{z}$ informacijami in svojo infrastrukturo.

\section{Pisarne za prenos tehnologij}

Slovenija podpira tudi dejavnost prenosa tehnologij, tehnološkega razvoja in inovativnosti javnih raziskovalnih organizacij (J RO) z namenom prenosa znanja in tehnologij v gospodarstvo. Aktivnosti pisarn za prenos tehnologij (glej http://www.podjetniski-portal.si/ustanavljampodjetje/inovativno-okolje/pisarne-za-prenos-tehnologij):

- postopki pred prevzemom intelektualne lastnine na matični J RO; na primer prijava izuma/priprava osnutka patentne prijave;

- postopki ščitenja intelektualne lastnine, na primer izpeljava postopkov zaščite s pomočjo patentnih zastopnikov, priprava pogodb $z$ določbami glede lastništva ter trženja, ocenjevanje tržnega potenciala, ocenjevanje smiselnosti zaščite IL, začetno financiranje patentnih prijav;

- postopki trženja intelektualne lastnine, na primer ocenjevanje tržnega know-howa, priprava tehnoloških ponudb, pasivno trženje - oglaševanje v primernih bazah, aktivno trženje tehnoloških ponudb - sejmi/konference/obiski podjetij, aktivno iskanje s pomočjo patentnih baz in tržnih podatkov, priprava sporazumov;

- spremljevalne aktivnosti, na primer spremljanje in evidentiranje dejavnosti prenosa tehnologij, nudenje informacij o virih financiranja, nudenje informacij v zvezi $\mathrm{z}$ razpisi, pomoč, ko gre za sodelovanje raziskovalne skupine $z$ gospodarskim subjektom, izobraževanja s področja prenosa tehnologij na J RO, promocija prenosa tehnologij, promocija dejavnosti konzorcija;

- ustanavljanje odcepljenih podjetij (spin-off in spin-out podjetij), na primer priprava dokumentacije za odobritev odcepljenega podjetja na matičnem J R O, oblikovanje ekipe, izdelava poslovnega načrta, pridobivanje $\mathrm{VC}$ in razpisnih sredstev.

\section{O aktivnih slovenski izumiteljih}

Po navedbah dr. Ane Hafner združenje izumiteljev Aktivni slovenski izumitelji deluje v okviru zavoda Inovatorski center A S - Aktivni slo- 
venski inovatorji. Nastalo je leta 2005, ko je v Sloveniji obstajalo le še nekaj društev inovatorjev, vendar so bila tudi ta zaradi pomanjkanja sredstev nedelujoča. Združenje zastopa in med seboj povezuje tako imenovane samostojne izumitelje (independent inventors). Gre za ljudi, ki izumljajo sami, izven organizacijskih okvirov, in se zato bistveno razlikujejo od inovatorjev, ki so zaposleni $\mathrm{v}$ (večjih) podjetjih in $\mathrm{R} R-$ organizacijah. Prek Mednarodne federacije združenj inovatorjev (I F IA) se ASI povezuje in izmenjuje izkušnje tudi s tujimi združenji izumiteljev.

Vsak samostojni izumitelj ima dve možnosti: svojo inovacijo lahko trži sam v okviru lastnega podjetja ali pa jo skuša licencirati drugemu podjetju in se sam ne ukvarja s proizvodnjo ter trženjem. Število slednjih je v Sloveniji še vedno zelo visoko. Podobno pripada posameznikom v Sloveniji $40 \%$ podeljenih nacionalnih patentov, na Madžarskem $75 \%$, na Norveškem 52 \%, na Irskem 43\%, v Belgiji 42 \%, v Avstriji 41\%, na Finskem $35 \%$, na Švedskem 34\% (glej https://www.ifia.com). V združenje AS I sta vključeni obe omenjeni skupini, članov je bilo v 1. 2014 približno 200, del aktivnosti pa usmerjajo tudi v mlade (na primer delavnice in seminarji na osnovnih in srednjih šolah ter fakultetah). Del aktivnosti poteka v Tehniškem muzeju Slovenije, ki v sodelovanju z A S I vsako leto organizira tudi Dneve inovatorjev, ki poleg razstave in izmenjave izkušenj ponujajo tudi izobraževalne vsebine.

\section{Coworking}

Gre za relativno novo obliko podpore mladim inventorjem in podjetnikom. To je dinamična oblika skupnega dela mladih, ki delajo v skupnih prostorih in si pri tem pomagajo ter izmenjujejo izkušnje. To praviloma prispeva k večji ustvarjalnosti, motivaciji in ustvarjanju skupnih projektov. Pogosto sta sodelujočim na voljo tudi dodatna pomoč in podpora, kot na primer I K T infrastruktura, literatura, sejna soba, pravniške storitve, skupni tiskalniki in računovodske storitve ipd.

\section{Vprašanja za utrjevanje}

1. Naštejte najpogostejše oblike financiranja novosti in njihove lastnosti.

2. Kaj lahko pričakujete od tehnoloških parkov? Kaj od »coworkinga«?

3. Kdo so poslovni angeli in kako delujejo? 



\section{Literatura}

Likar, B. 2007. Managing Innovation and R\&D Processes in EU Environment. Ljubljana: Korona plus.

Likar, B., J. Demšar, P. Fatur, D. Križaj, V. Pečjak, S. Sitar, D. Trček, N. Trunk Širca. 200o. Inovativnost za mlade. Ljubljana: Korona plus.

Likar B., D. Križaj in P. Fatur. 2006. Management inoviranja. Koper: Fakulteta za management.

Mulej, M., in Z.Ženko. 2004. Dialektična teorija sistemov in invencijsko-inovacijski management. Maribor: Management Forum.

Rogers, E. M. 2003. Diffusion of Innovation. 5. izd. New York: Simon and Schuster.

Samuelson, P. A., in W. D. Nordhaus. 1995. Economics. 15. izd. New York: McGraw-Hill. 


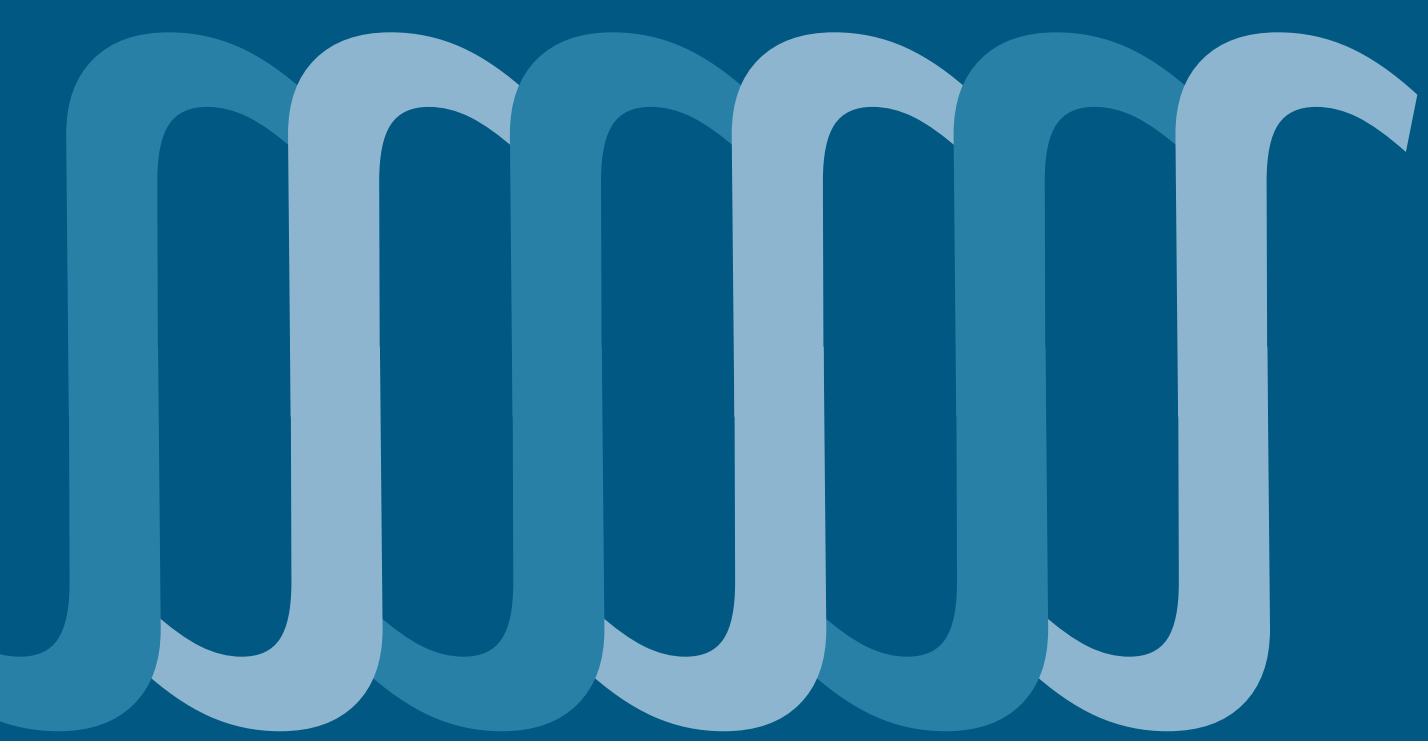

Založba Univerze na Primorskem www.hippocampus.si 